\title{
ESTIMATIVAS DE PARÂMETROS GENÉTICOS E FENOTÍPICOS EM DUAS POPULAÇÕES DE ARROZ DE SEQUEIRO E IMPLICAÇÕES PARA O MELHORAMENTO
}

\section{ANA CLÁUdIA DE CARVALHO BADAN}

(Bióloga)

ORIENTAdor: Prof. Dr. Isaias Olívio GeRaldi

Dissertação apresentada à Escola Superior de Agricultura "Luiz de Queiroz", Universidade de São Paulo, para obtenção do título de Mestre em Agronomia. Área de Concentração: Genética e Melhoramento de Plantas.

PIRACICABA

Estado de São Paulo - Brasil

Março - 1999 


\section{ERRATA}

\begin{tabular}{|c|c|c|c|c|}
\hline p. & item & linha & onde se lê & leia-se \\
\hline$x i i$ & summary & terceira & ...genotic & ...genetic \\
\hline 1 & 1 & oitova & $\begin{array}{l}\text {...utilizar a Seleção Recorrente na } \\
\text { tentativa de ampliar a base genética... }\end{array}$ & $\begin{array}{l}\text {...utilizar a Seleção Recorrente na } \\
\text { tentativa de explorar a variabilidade } \\
\text { genética... }\end{array}$ \\
\hline 10 & 2 & quinta & $\begin{array}{l}. .(C L A T, \text { Colômbia }) \text { utilizando a } \\
\text { Seleçâo Recorrente, têm observado... }\end{array}$ & ...(CLAT, Colômbia) têm observado... \\
\hline 12 & 3 & sexta e sétima & $\begin{array}{l}\text {... L foi obtida do programa de } \\
\text { melhoramento de arroz de sequeiro do } \\
\text { CNPAF... }\end{array}$ & $\begin{array}{l}\text {... L foi obtida do programa de } \\
\text { melhoramento do IAPAR e foi } \\
\text { incorporada ao programa de } \\
\text { melhoramento de arroz de sequeiro do } \\
\text { CNPAF }\end{array}$ \\
\hline 15 & 3.5 .1 & $\begin{array}{l}\text { décima sétimae } \\
\text { décima oitava }\end{array}$ & $\begin{array}{l}\text { Comparação entre as populaçôes e } \\
\text { linhagens quanto à média }\end{array}$ & $\begin{array}{l}\text { Comparações entre as populações e } \\
\text { linhagens quanto às médias }\end{array}$ \\
\hline 18 & 3.5 .2 & $\begin{array}{l}\text { primeira e } \\
\text { segunda }\end{array}$ & $\begin{array}{l}\text { Comparação entre as populações } e \\
\text { linhagens quanto à variância }\end{array}$ & $\begin{array}{l}\text { Comparações entre as populações } e \\
\text { linhagens quanto às variâncias }\end{array}$ \\
\hline 27 & Tabela 13 & décima quinta & 2,96 & 28,23 \\
\hline 28 & Tabela 15 & $\begin{array}{l}\text { trigésima } \\
\text { segunda }\end{array}$ & ... pelo teste de $F$ & ...pelo teste de $t$ \\
\hline
\end{tabular}

BADAN, A.C.C. Estimativas de parâmetros genéticos e fenotípicos em duas populações de arroz de sequeiro e implicações para o melhoramento. Mestrado ESALQ. 1999. 5Ip. 
Dados Internacionais de Catalogação na Publicação (CIP) DIVISÃo DE BIBLIOTECA E DOCUMENTAÇĀO - Campus "Luiz de Queiroz"/USP

Badan, Ana Cláudia de Carvalho

Estimativas de paràmetros genéticos e fenotípicos em duas populaçōes de arroz de sequeiro

e implicaçōes para o melhoramento / Ana Cláudia de Carvalho Badan. - - Piracicaba, 1999

$51 \mathrm{p}$.

Dissertação (mestrado) - Escola Superior de Agricultura Luiz de Queiroz, 1999.

Bibliografia.

1. Arroz de sequeiro 2. Herdabilidade 3. Melhoramento genético vegetal 4. Parâmetro genético 5. População de planta 6. Seleçāo recorrente 7. Variaçāo fenotipica 8 . Variaçāo genética I. Titulo

CDD 633.18

Penmitda a copia total ou parcial deste documento, desde que cifada a fonte 0 \% ator 


\section{AGRADECIMENTOS}

Cada vez mais tenho a certeza de que nada pode e nem deve ser construído sozinho. Informações, influências e incentivos são movimentos oscilatórios que batem e rebatem auxiliando na modelagem de uma forma. Difícil é conseguir delimitar quais foram os formões que auxiliaram neste trabalho.

Pela oportunidade que me proporcionaram de conhecer um centro de pesquisa como o Centro Internacional de Agricultura Tropical (CIAT), Colômbia, pelas discussões que muitas vezes esclareceram e outras vezes geraram dúvidas, concretizando o verdadeiro processo de aprendizagem, minha maior homenagem e meu sincero agradecimento aos queridos orientador Prof. Dr. Isaias Olívio Geraldi e co-orientador PqC. Dr. Elcio Perpétuo Guimarães.

Pela grande influência durante estágio no Instituto Agronômico de Campinas (IAC), que me levou a optar pela área de melhoramento genético, ao PqC. Dr. José Alfredo Usberti Filho.

Pelos ensinamentos em Genética, aos professores do Departamento de Genética da ESALQ/USP.

Pela viabilização das operações dentro do Departamento de Genética, aos funcionários Léa, Carmen, Adriana, Oberdan, Fernando, Beth e Carlos.

Pela montagem do experimento na Colômbia e pelos ensinamentos sobre a cultura do arroz, à amiga "complementaria", Eng. Agr. Yolima Ospina Rey, e ao amigo MSc. Jaime Borrero.

Pelos auxílios na parte de campo, aos Jaime, Pacho, Lucho, Polo, funcionários do CIAT.

Pela facilitação nas operações dentro do CIAT, ao PqC. Dr. Marc Châtel, ao PqC. Dr. Luis Sanint e aos funcionários Elsy, Clara, Liz e Jairo Barona. Pelos ensinamentos sobre estatística, ao estatístico Jaime Silva, funcionário do CIAT. 
Pelos auxílios na busca de livros, revistas e teses às bibliotecánias e aos tuw ionários das bibliotecas da ESALQ, em especial à S vana, à Eliana e à Beth e das bibliotecas do CIAT e do IAC.

Pelo auxílio financeiro, ao CNPq e ao CIAT.

Pelo ensino do programa estatístico SAS, ao Prof. Carlos Tadeu dos Santos Dias do Departamento de Estatística da ESALQ.

Pela ajuda na elaboração do resumo em inglês à Sra. Adrienne Toledo.

Pelas valiosas dicas, que só mesmo amigos são capazes de dar, à Silvana, à Sandrinha, ao Nivaldo, à Natália, ao Edson, ao Rhainer, ao Rogério, ao Chico, ao Julianno, ao Gilberto, ao Cláudio, ao André Bertoldi, ao Eduardo Graterol, à Ana Palmira e ao Ermelindo.

Pelos bons momentos divididos, ao Glauco.

Pela eterna lição de que, com vontade, determinação e perseverança a gente cria oportunidades e chega lá, ao papai, mamãe e a Fafá. 


\section{SUMÁRIO}

Página

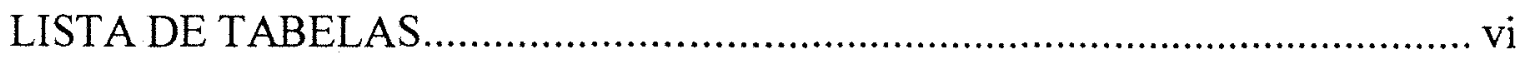

LISTA DE ABREVIATURAS E SÍMBOLOS …............................................. ix

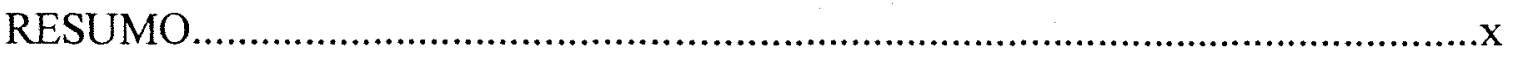

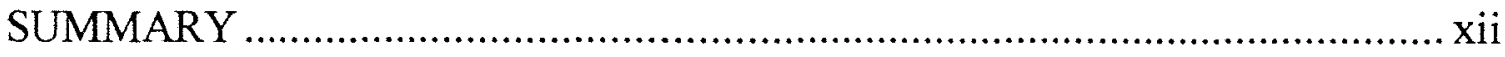

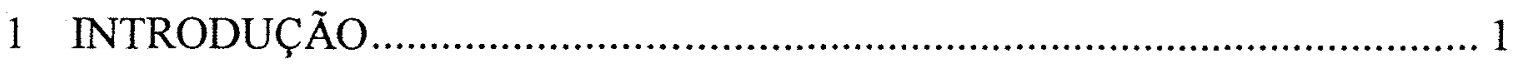

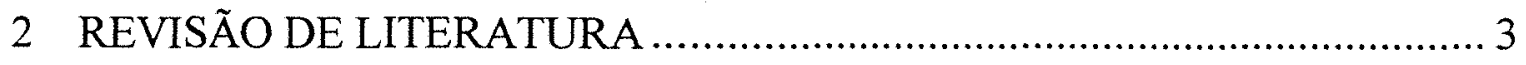

3 MATERIAIS E MÉTODOS …..................................................................11

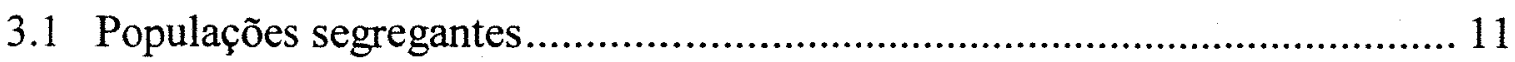

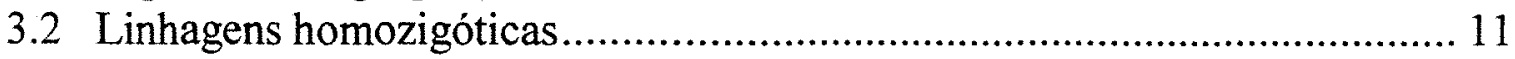

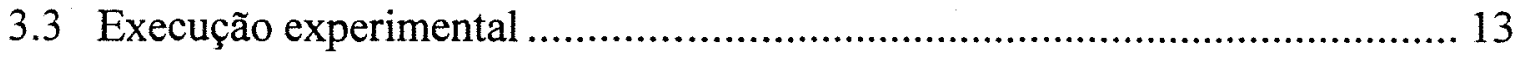

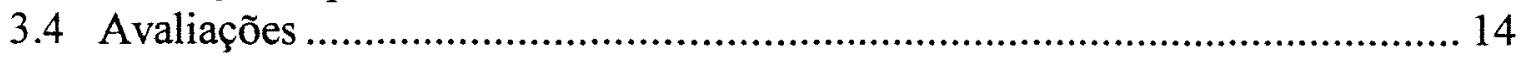

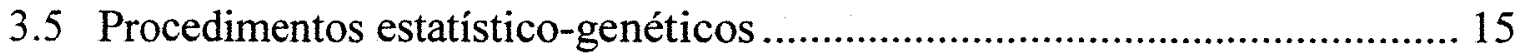

3.5.1 Comparação entre as populações e linhagens quanto à média..............................15

3.5.2 Comparação entre as populações quanto à variância ..........................................17

3.5.3 Análise de variância dentro de população .........................................................19

3.5.4 Estimativa de parâmetros genéticos e fenotípicos................................................21

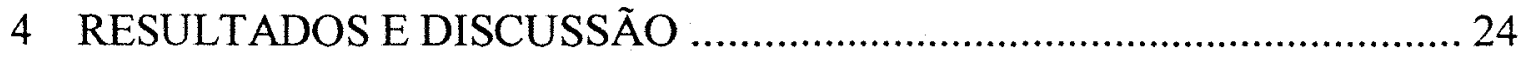

4.1 Comparação entre linhagens e populações segregantes em termos de média24

4.2 Comparação entre populações segregantes em termos de variância.............. 30

4.3 Considerações gerais sobre as duas populações quanto aos diferentes

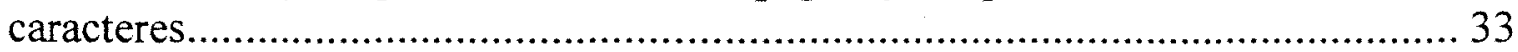

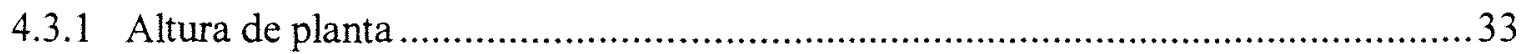

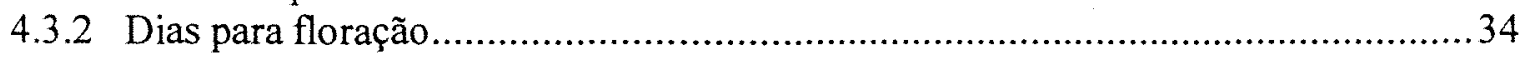

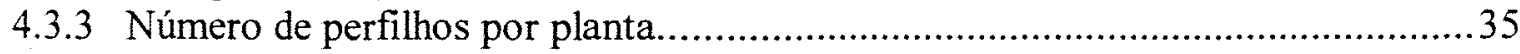

4.3.4 Número de panículas por planta........................................................................36

4.3.5 Produção de grãos por planta em plantas férteis e macho-estéreis .........................37

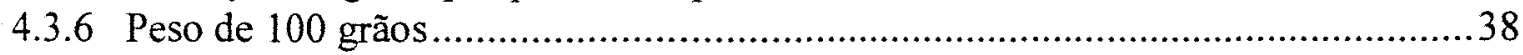

4.4 Estimativas de parâmetros genético e fenotípicos........................................ 38

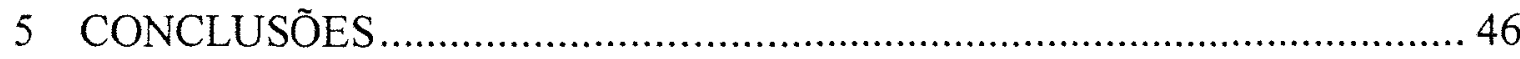

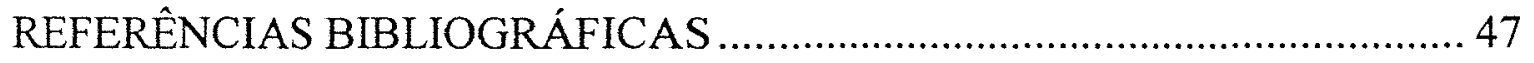




\section{LISTA DE TABELAS}

Página

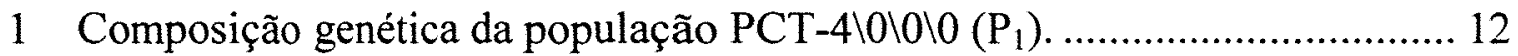

2 Características das sete linhagens avaliadas para a composição da população PCT-4\0\0\0 com relação a altura de plantas (ALT) e dias para floração

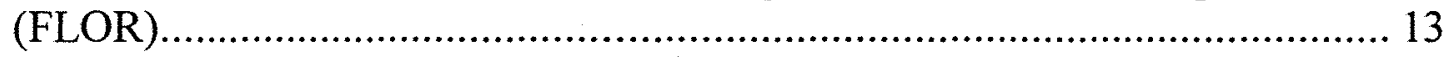

3 Valores de média de cada população e linhagem, em cada repetição.............. 16

4 Análise de variância com base nas médias dos tratamentos.......................... 17

5 Valores de variância de cada população, em cada repetição............................18

6 Análise de variância das variâncias dos tratamentos, com dados transformados pela escala logarítmica.......................................................................... 18

7 Análise de variância, considerando cada população e linhagem separadamente, para cada repetição. .............................................................................. 20

8 Análise de variância para cada repetição, unindo as linhagens em um único

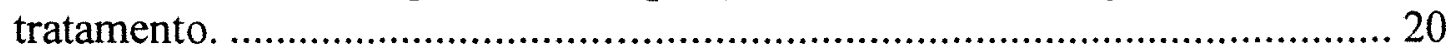

9 Análise de variância, considerando-se as quatro repetições, unindo as linhagens

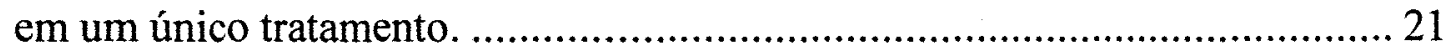

10 Valores de média das características altura de planta (ALT), dias para floração (FLOR), número de perfilhos por planta (NPERF), número de panículas por planta (NPAN), produção de grãos por planta (PROD), peso de 100 grãos $\left(\mathrm{P}_{100}\right)$ das populações $\mathrm{P}_{0}$ e $\mathrm{P}_{1}$ e das linhagens $\mathrm{L}_{1}$ a $\mathrm{L}_{5}$, nas quatro repetições. 25

11 Valores de média das características produção de grãos de plantas férteis (PRODF) e produção de grãos de plantas macho-estéreis (PRODMS) das

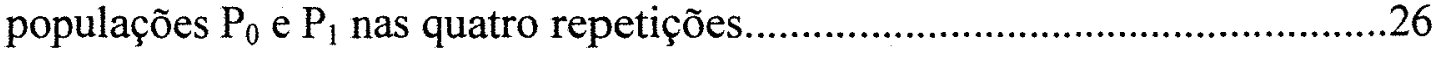

12 Fontes de variação (FV), graus de liberdade (GL) e quadrados médios (QM) para a análise de variância da média dos caracteres altura de planta (ALT), dias para floração (FLOR), número de perfilhos por planta (NPERF), número de panículas por planta (NPAN) das linhagens $L_{1}$ a $L_{5}$ e populações $P_{0}$ e $P_{1} .26$

13 Fontes de variação (FV), graus de liberdade (GL) e quadrados médios (QM) para a análise de variância da média dos caracteres produção de grãos por planta (PROD), peso de 100 grãos $\left(\mathrm{P}_{100}\right)$ e produção de grãos de plantas férteis (PRODF) das linhagens $\mathrm{L}_{1}$ a $\mathrm{L}_{5}$ e populações $\mathrm{P}_{0}$ e $\mathrm{P}_{1}$

14 Fontes de variação (FV), graus de liberdade (GL) e quadrados médios (QM) para a análise de variância da média dos caracteres produção de grãos de plantas férteis (PRODF) e produção de grãos de plantas macho-estéreis (PRODMS) das populações $\mathrm{P}_{0}$ e $\mathrm{P}_{1}$ 


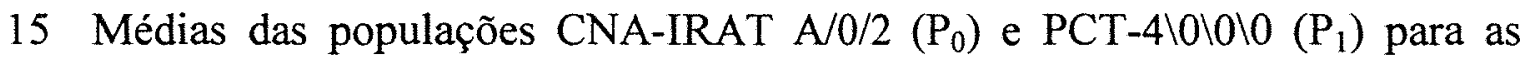
características altura de planta (ALT), dias para floração (FLOR), número de perfilhos por planta (NPERF), número de panículas por planta (NPAN), produção de grãos por planta (PROD), produção de grãos de plantas férteis (PRODF), produção de grãos de plantas macho-estéreis (PRODMS), peso de 100 grãos $\left(\mathrm{P}_{100}\right)$. 28

16 Valores médios das características altura de planta (ALT), dias para floração (FLOR), número de perfilhos por planta (NPERF), número de panículas por planta (NPAN), produção de grãos por planta (PROD) e peso de 100 grãos das linhagens utilizadas como parentais para a formação da população PCT$4 \backslash 0 \backslash 0 \backslash 0\left(\mathrm{P}_{1}\right)$

17 Valores de variância das características altura de planta, dias para floração, número de perfilhos por planta, número de panículas por planta, produção de grãos por planta, produção de grãos de plantas férteis, produção de grãos de plantas macho-estéreis, peso de 100 grãos das populações CNA-IRAT A/0/2

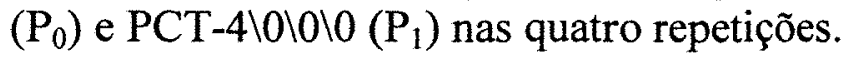
30

18 Fontes de variação (FV), graus de liberdade (GL) e quadrados médios (QM) para a análise de variância da variância dos caracteres altura de planta (ALT), dias para floração (FLOR), número de perfilhos por planta (NPERF), número de panículas por planta (NPAN) das populações $\mathrm{P}_{0}$ e $\mathrm{P}_{1}$. 31

19 Fontes de variação (FV), graus de liberdade (GL) e quadrados médios (QM) para a análise de variância da variância dos caracteres produção de grãos por planta (PROD), produção de grãos de plantas férteis (PRODF), produção de grãos de plantas macho-estéreis (PRODMS), peso de 100 grãos $\left(\mathrm{P}_{100}\right)$ das populações $\mathrm{P}_{0}$ e $\mathrm{P}_{1}$. 31

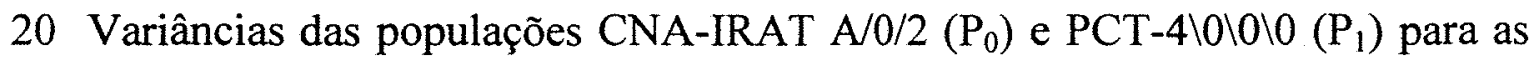
características altura de planta, dias para floração, número de perfilhos por planta, número de panículas por planta, produção de grãos por planta, produção de grãos de plantas férteis, produção de grãos de plantas macho-

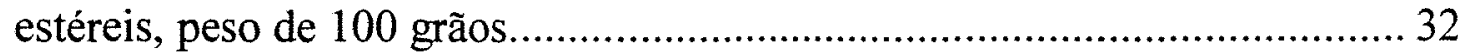

21 Variâncias dentro de populações para a característica altura de planta. ........ 38

22 Variâncias dentro de populações para a característica dias para floração....... 38

23 Variâncias dentro de populações para a característica número de perfilhos por

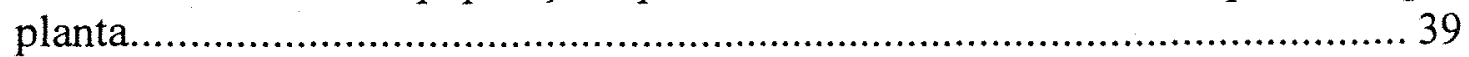

24 Variâncias dentro de populações para a característica número de panículas por

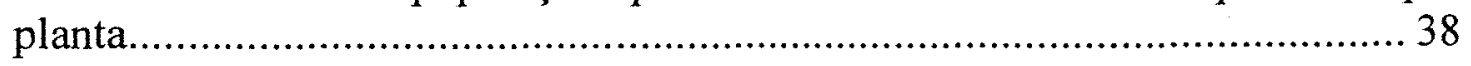

25 Variâncias dentro de populações para a característica produção de grãos por planta. 39

26 Variâncias dentro de populações para a característica produção de grãos de plantas férteis. 40 
27 Variâncias dentro de populações para a característica peso de 100 grãos. ..... 40

28 Estimativas de variância ambiental e genética para as duas populações e respectivas estimativas de parâmetros genético-estatísticos para as características altura de planta (ALT), dias para floração (FLOR), número de perfilhos por planta (NPERF), número de panículas por planta (NPAN), produção de grãos por planta (PROD) e peso de 100 grãos $\left(\mathrm{P}_{100}\right)$................. 41 


\section{LISTA DE ABREVIATURAS E SÍMBOLOS}

CIAT- Centro Internacional de Agricultura Tropical

CIRAD-Centre de Coopération Internationale en Recherche

Agronomique pour le Développement

CIRAD-CA Centre de Coopération Internationale en Recherche

Agronomique pour le Développement. Département des cultures annuelles.

EMBRAPA- Empresa Brasileira de Pesquisa Agropecuária

IRAT - International Recherche en Agronomie Tropical

IRRI- International Rice Research Institute

CNPAF- Centro Nacional de Pesquisa de Arroz e Feijão, pertencente

à EMBRAPA. 


\title{
ESTIMATIVAS DE PARÂMETROS GENÉTICOS E FENOTÍPICOS EM \\ DUAS POPULAÇÕES DE ARROZ DE SEQUEIRO E IMPLICAÇÕES \\ PARA O MELHORAMENTO.
}

\author{
Autora: Ana Cláudia de Carvalho Badan \\ Orientador: Prof. Dr. Isaias Olívio Geraldi
}

\section{RESUMO}

As estimativas de parâmetros genéticos e fenotípicos de uma população possibilitam a avaliação de seu potencial para fins de melhoramento. Foram estimadas as variâncias genéticas e fenotípicas, herdabilidades e coeficientes de variação genético em duas populações de arroz de sequeiro, a

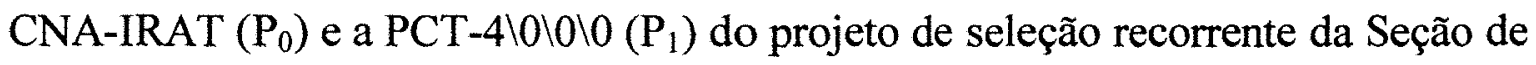
Arroz do Centro Internacional de Agricultura Tropical (CIAT, Colômbia), a partir de um experimento em blocos ao acaso, com quatro repetições, instalado na Estacion Experimental "La Libertad", Villavicencio, Colômbia, no primeiro semestre do ano agrícola 1995. Foram avaliadas as características altura da planta, dias para floração, número de perfilhos por planta, número de panículas por planta, produção de grãos por planta, peso de 100 grãos e fertilidade, e comparouse as duas populações com relação ao potencial destas em programas de melhoramento. As comparações entre médias e variâncias foram feitas através de análises de variâncias, onde as cinco linhagens, que haviam sido utilizadas como parentais para a formação de $\mathrm{P}_{1}$ também foram utilizadas como tratamentos. Para estimar as variâncias genéticas, considerou-se que a variância existente dentro de linhagens homozigotas correspondia à variância ambiental, e por diferença estimou-se as variâncias genéticas. Concluiu-se que a população $\mathrm{P}_{1}$ diferiu da $\mathrm{P}_{0}$ em termos de média, para as características altura de planta, dias para floração, número de perfilhos por planta, número de panículas por planta e peso de cem grãos. Em termos de variância, as populações diferiram entre si para as características dias para floração, número de perfilhos por planta e número de panículas por planta. Com base nas estimativas de parâmetros genético- 
estatísticos, pode-se afirmar que a população $P_{1}$ apresenta-se mais favorável ao melhoramento genético para as características número de perfilhos por planta, número de panículas por planta e produção de grãos por planta que a população $\mathrm{P}_{0}$. A população $\mathrm{P}_{1}$ foi considerada superior à população $\mathrm{P}_{0}$ por ter apresentado diminuição na característica altura de planta e aumento em número de perfilhos por planta e número de panículas por planta.

Termos de indexação: arroz de sequeiro, herdabilidade, melhoramento genético vegetal, parâmetros genéticos, população de planta, seleção recorrente, variação genética, variação fenotípica. 


\title{
ESTIMATES OF GENETIC AND PHENOTYPIC PARAMETERS IN TWO \\ UPLAND RICE POPULATIONS AND BREEDING PERSPECTIVES
}

\author{
Author: Ana Cláudia de Carvalho Badan \\ Adviser: Prof. Dr. Isaias Olívio Geraldi
}

\section{SUMMARY}

The breeding potential of a population can be assessed from the estimates of genetic and phenotypic parameters. The genetic and phenotypic variances, heritability and coefficient of genotic variation were estimated for two

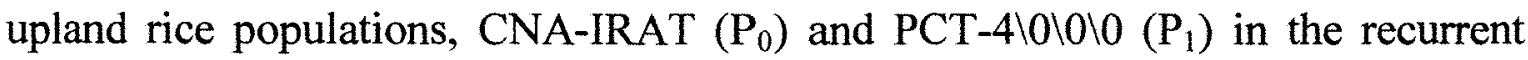
selection project of the Rice Division of the International Center for Tropical Agriculture (CIAT, Colombia). An experiment in randomized complete blocks design, with four replications, was carried out at the Estacion Experimental " $\mathrm{La}$ Libertad", Villavicencio, Colombia, May through September 1995. The traits plant height in $\mathrm{cm}$ (ALT), days to flowering (FLOR), number of tillers per plants (NPERF), number of panicles per plant (NPAN), grain yield per plant in $g$ (PROD), weight of 100 grains in $\mathrm{g}\left(\mathrm{P}_{100}\right)$ of the two populations were compared for the population potentials in breeding programs. The comparison between means and variances were made by analysis of variance, where the five lines which had been used as parents to form $\mathrm{P}_{1}$, were also used as treatments. The variance existing within the homozygotic lines was considered to correspond to environmental variance to estimate the genetic variances which were estimated by difference. The means of populations $\mathrm{P}_{1}$ and $\mathrm{P}_{0}$ differed for plant height, days to flowering, number of tillers per plant, number of panicles per plant and weight of 100 grains. In terms of variance, the populations differed for the traits days to flowering, number of tillers per plant and number of panicles. Based on the estimates of statistical-genetic parameters, population $P_{1}$ showed greater breeding potential for the traits number of tillers per plant, number of panicles per plant and grain yield per plant than population $\mathrm{P}_{0} . \mathrm{P}_{1}$ population was considered better than 
$P_{0}$ because of its lower plant height and and higher number of tillers and number of panicles per plant.

Key words: upland rice, heritability, plant breeding, genetic parameter, plant population, recurrent selection, genetic variation, phenotypic variation. 


\section{INTRODUÇÃO}

Avaliando diversos programas de melhoramento genético de arroz, vários autores têm apontado a restrita base genética da cultura como fator que incrementa a dificuldade em se quebrar patamares de produtividade (Cuevas-Perez et al., 1992; Dilday, 1990; Guimarães et al., 1993; 1996; Hargrove et al., 1980; Montalvan et al., 1998; Rangel et al., 1996). Como, em geral, os programas de melhoramento genético têm como finalidade gerar genótipos superiores que possam substituir com vantagens aqueles já existentes, alguns deles passaram a utilizar a Seleção Recorrente na tentativa de ampliar a base genética da cultura e assim promover melhor recombinação entre genes de interesse, sendo eles relacionados diretamente a produtividade ou não, como exemplo, plantas com tolerância a certas enfermidades. Até há pouco tempo, esse método era de uso quase que exclusivo para plantas alógamas por depender da realização de vários cruzamentos (Allard, 1971); entretanto, a indução da macho-esterilidade em plantas de arroz por Singh \& Ikehashi (1981), através da mutação, veio possibilitar cruzamentos entre plantas de arroz sem necessidade do trabalho humano de emasculação e cruzamento dirigido (Borém, 1997), deixando com que os cruzamentos fossem feitos ao acaso na população, com o auxílio do vento.

Com esse advento facilitador, alguns programas de melhoramento genético de arroz na Colômbia, no Brasil, no Chile, na Venezuela, no Uruguai, no Peru, e em alguns países da África e Madagascar, passaram a utilizar-se desse método, como apresentado em diversos trabalhos (Guimarães, 1997). Esse método 
envolve a criação de populações com ampla base genética, onde se seleciona genótipos favoráveis para serem recombinados a seguir. $O$ intuito é o de acumular caracteres favoráveis em um único genótipo. Muitas destas populações criadas, têm sido intercambiadas entre países da América Latina, e isso, reforça ainda mais a necessidade de se conhecer o potencial genético das populações formadas, devido a possibilidade de ampla utilização destes materiais.

As estimativas de parâmetros genéticos e fenotípicos, são utilizadas para se conhecer o potencial genético das populações. É com base nelas que se tem uma idéia da possibilidade de seleção de caracteres favoráveis. Em geral, caracteres que apresentam alta herdabilidade, tem maiores chances de serem selecionados em gerações precoces. Do mesmo modo, populações que apresentam maior variabilidade têm maior chance de conter genótipos favoráveis. Por isso, ao se iniciar qualquer estudo com uma população deve-se ter idéia do possível comportamento dela em gerações futuras, para que se otimize os gastos de tempo, dinheiro, trabalho ou mesmo de espaço, na tentativa de obter genótipos superiores aos já existentes.

Este trabalho tem por objetivo caracterizar e estimar parâmetros genéticos de duas populações de arroz de sequeiro para solos ácidos do projeto de Seleção Recorrente do Centro Internacional de Agricultura Tropical (CIAT/Colômbia), e avaliar o potencial das mesmas para o melhoramento. 


\section{REVISÃO DE LITERATURA}

Em geral, os programas de melhoramento genético têm como finalidade gerar genótipos superiores portadores de caracteres desejáveis, inéditos ou não, que possam substituir com vantagens aqueles já existentes. Para isso, as várias técnicas utilizadas vão desde a geração e ampliação da variabilidade da cultura até a seleção e multiplicação dos melhores genótipos. O sucesso na seleção desses genótipos está diretamente relacionado à variabilidade genética e herdabilidade dos caracteres e estes parâmetros quase sempre são influenciados por fatores ambientais (Chauhan et al., 1997). Para se obter eficiência na seleção busca-se eliminar as influências do ambiente sobre o comportamento dos genótipos a serem escolhidos, uma vez que se conhece que a característica fenotípica é controlada pelo fator genético e ambiental. O controle ambiental pode ser feito através de técnicas experimentais, de forma que a identificação da fração hereditária do genótipo torna-se possível. Vega (1988) afirmou que esse controle consiste na correção das observações fenotípicas originais causadas por diferenças no ambiente e pode ser isolado em termos numéricos ao se realizar uma análise de variância.

O conceito de herdabilidade surgiu como um índice para que o valor fenotípico sirva como guia para o valor genético (Falconer, 1987). Posteriormente este conceito foi subdividido em herdabilidade em sentido amplo e a herdabilidade em sentido restrito. Em sentido amplo, trata-se da proporção variância genética/variância fenotípica e, em sentido restrito, trata-se da proporção variância 
aditiva/variância fenotípica (Vega, 1988). Os coeficientes de herdabilidade podem variar conforme a população, a característica estudada, o método de estimação, a diversidade na população, o nível de endogamia da população, o tamanho da amostra avaliada, o número e o tipo de ambientes considerados, a unidade experimental considerada, a precisão na condução experimental e a coleta de dados. O cálculo da herdabilidade pode ser feito de diversas maneiras, e para isso devem ser levados em consideração os recursos genéticos disponíveis e a finalidade da estimativa (Borém, 1997). É usual existir uma associação entre os valores de alta herdabilidade com a expressão de caracteres controlados por poucos genes e a de baixa herdabilidade com a expressão de caracteres controlados por muitos genes. Por esse motivo, os caracteres variam imensamente quanto a herdabilidade. Um caráter com alta herdabilidade usualmente poderá ser selecionado em fase inicial de programa de melhoramento, o que reduz custos e mão de obra.

Chandraratna (1963) apresentou estimativas de herdabilidade obtidas por vários autores, para diferentes características da cultura do arroz. Os valores citados variam bastante entre si para uma mesma característica mas, de uma maneira geral, os valores mais baixos de herdabilidade são encontrados para as características número e comprimento de panículas.

Sakai \& Niles (1957) com base em populações $F_{2}$ e $F_{3}$ de arroz de sequeiro oriundas de cruzamentos entre as variedades Panduruwi e Vellai Illankalayan 28061 estimaram as herdabilidades para as características altura de plantas $(48,1 \%$ e $61,2 \%$ respectivamente), produção de grãos $(5,3 \%$ e $39,0 \%$ respectivamente) e comprimento da panícula ( $4,1 \%$ e $6,9 \%$ respectivamente). Os autores relatam que os baixos valores de herdabilidade encontrados podem estar relacionados aos efeitos de dominância dos genes ou com efeito ambiental.

Verma et al. (1994) avaliaram 27 famílias autofecundadas a partir de um cruzamento triplo entre arroz índico Himalaya $741 \mathrm{~m}$, HPU5101 e seu híbrido e 
estimaram que as características altura de plantas, dias para floração e comprimento de grãos apresentavam alto, moderado e baixo valor de herdabilidade respectivamente. Eles afirmam haver efeito de dominância controlando todos os caracteres exceto a altura.

De uma maneira resumida pode-se afirmar que altos coeficientes de herdabilidade foram obtidos por Ashvani et al. (1997) para as caracteristicas dias para floração, número de panículas, produção de grãos, peso de 100 grãos e número de grãos por panícula, ao avaliarem 22 genótipos, na Índia; por Chaubey \& Singh (1994) para número total de espigas, produção de grãos por planta e peso de 100 grãos ao conduzirem experimentos com 20 variedades de arroz em Azangarh, Índia, em 1982; por Datke et al. (1997) para altura, dias para floração, produção de grãos e número de espiguetas por panícula ao avaliarem famílias $\mathrm{F}_{6}$; por Mehetre et al. (1996) para altura $(91,2 \%)$ em familias de geração $F_{2}$ obtidas por mutação $\left(M_{2}\right)$; por Parmasivan (1981) para as características comprimento de panícula $(94,6 \%)$ e número de grãos por panícula (93,3\%); por Saravanan \& Senthil (1997) para as características altura $(99,1 \%)$, dias para floração $(98,2 \%)$ e número de perfilhos por planta $(98,2 \%)$, ao avaliarem três linhas macho-estéreis e seus híbridos; por Sharma \& Hore (1997) para as características dias para floração, produção de grãos, peso de 100 grãos, peso de panícula e número de grãos por panícula ao avaliarem 50 variedades na Índia.

Embora algumas características como produção de grãos, dias para floração, tenham aparecido em vários trabalhos citados como sendo de alta herdabilidade, há ainda outros autores que relatam existir moderada e baixa herdabilidade para esses caracteres. Basavaraja et al. (1997) afirmam haver baixa herdabilidade para produção de grãos e associam isso a um baixo ganho genético; Mehetre et al. (1996) obtiveram herdabilidade de 54,9\% para a característica produção de grãos em famílias $\mathrm{M}_{2}$ e Mishra et al. (1996) encontraram baixo valor de herdabilidade para número de perfilhos. Parmasivan (1981) encontrou 
moderados valores para as características peso de 100 grãos $(54,7 \%)$ e produção de grãos por planta $(58,9 \%)$, e baixo valor para número de panículas $(16,2 \%)$.

As discussões que acompanham os resultados de estimativas dos parâmetros genéticos, de uma maneira geral, abordam a eficiência de seleção para um ou outro caráter, a possibilidade do caráter estar sendo controlado por genes de efeito aditivo ou dominante, favorecendo a utilização de um ou outro método de melhoramento, ou ainda, a diferença entre estimativas de herdabilidade de uma geração para outra. Neste sentido, Chauhan (1998), ao encontrar herdabilidades no sentido amplo em gerações $F_{2}$ com valores maiores do que em gerações $F_{3}$ para as características tamanho, forma e peso de grãos, sugeriu haver predominância de genes não aditivos controlando estes caracteres o que levaria a uma restrição da possibilidade de seleção em gerações precoces. Rao (1996) sugeriu que havendo coeficiente de variação genético $\left(\mathrm{CV}_{\mathrm{g}}\right)$ e herdabilidade altos a seleção pode ser eficiente em gerações precoces. Basavaraja et al. (1997), Sakai \& Niles (1957) e Sakai (1963) discutiram que a maioria das plantas autógamas apresentam herdabilidade muito baixa na geração $\mathrm{F}_{2}$, de forma que torna-se dificil selecionar genótipos superiores nesta fase; entretanto, nas gerações sucessivas essa herdabilidade tende a aumentar, uma vez que há tendência de se diminuir a heterozigosidade. Dessa maneira, a seleção para caracteres como produção não deve ser feita em gerações precoces.

Outros autores que estimaram e discutiram os parâmetros genéticos de populações de arroz foram Almeida et al. (1998), Morais et al. (1997b); Morais et al. (1998), Rangel et al. (1998), Rodriguez et al. (1998) e Santos et al. (1997). O modo de manejo das populações estudadas por estes autores foi através de cruzamentos múltiplos.

Almeida et al. (1998), em experimento com famílias $\mathrm{S}_{0: 6}$ da população de arroz irrigado CNA-IRAT 4 avaliado em Teresina (PI), no ano agrícola 1997/98, estimaram valores de herdabilidade das características altura da 
planta $(88,8 \%)$, dias para floração $(95,5 \%)$, número de panículas por planta por metro quadrado (15,9\%), número de espiguetas por panícula $(82,4 \%)$, peso de 1000 grãos $(87,2 \%)$ e porcentagem de grãos cheios por panícula $(64,6 \%)$. Estimaram ainda os valores de $\left(\mathrm{CV}_{\mathrm{g}} / \mathrm{CV}_{\mathrm{e}}\right)$, também denominado $\mathrm{b}$, encontrando valores maiores que 1 para quase todas características, exceto número de panículas e produção de grãos. Indicaram, com base nestes dados, que trata-se de uma população com possibilidade de sucesso na seleção de genótipos superiores.

Morais et al. (1997b) trabalhando em Goianira (GO), no ano agrícola de 1989/90, com 60 famílias $\mathrm{S}_{0: 2}$ e 59 famílias de meio-irmãos autofecundadas da população de arroz irrigado CNA-IRAT 4/0/3 avaliaram as características altura de plantas, número de panículas por planta, comprimento de panícula, peso de 100 grãos e produção de grãos. Os coeficientes de variação experimental (CV) mais altos foram obtidos para as características número de panículas e produção de grãos por planta para ambas as populações. Os coeficientes de variação genética $\left(\mathrm{CV}_{\mathrm{g}}\right)$ mais altos foram obtidos para as características produção de grãos por planta, número de panículas por planta e altura de planta, indicando que é possível obter ganhos genéticos para essas características desde que não haja perda de alelos favoráveis ao longo das gerações. Os valores de herdabilidade encontrados para as características altura, comprimento de panículas e peso de 100 grãos ao nível de média dentro de famílias foram de $70,3 \%, 60,9 \%$ e $64,5 \%$ para a população de meio-irmãos autofecundada e de $95,1 \%, 87,2 \%$ e $95,5 \%$ para a população $\mathrm{S}_{0: 2}$, respectivamente. Os autores sugerem que nos primeiros ciclos de seleção a característica altura de plantas deva ser favorecida pela sua maior herdabilidade.

Morais et al. (1998) ao estudarem a população de arroz de sequeiro CG2 estimaram parâmetros genéticos e encontraram altos valores de coeficiente de variação genética $\left(\mathrm{CV}_{\mathrm{g}}\right)$ para as características classe de grãos $(27,5 \%)$, mancha de grãos $(25,7 \%)$, mancha parda $(26,3 \%)$, brusone de pescoço $(14,4 \%)$, produção de grãos $(12,9 \%)$ e indicaram que esses são os caracteres mais sujeitos a alterações se 
for continuado o processo seletivo. Estas mesmas características apresentaram os seguintes valores de herdabilidade: $81,7 \% ; 66,9 \% ; 74,6 \% ; 28,1 \% ; 53,0 \%$ respectivamente. Os caracteres que apresentam maiores valores de herdabilidade têm maior chance de atingir um progresso com seleção nas primeiras gerações.

Rangel et al. (1998) avaliaram famílias $\mathrm{S}_{0: 2}$ provenientes das populações de arroz irrigado CNA-IRAT 4PR/1/1 e CNA-IRAT 4ME/1/1, em Goianira (GO) e Formoso do Araguaia (TO) no ano agrícola 1992/93 e estimaram os parâmetros genéticos para as características dias para floração, produção de grãos, brusone na panícula e mancha parda e dividiram as populações em ciclo médio e curto. Os maiores valores de coeficiente de variação genética $\left(\mathrm{CV}_{\mathrm{g}}\right)$ encontrados foram para as características brusone na panícula e produção para ambas as populações. As menores estimativas de coeficiente de variação genética $\left(\mathrm{CV}_{\mathrm{g}}\right)$ foram para a característica dias para floração, e isso se deve à tentativa de uniformizar essa característica no primeiro ciclo de seleção. Os autores consideraram como alta a herdabilidade encontrada para a característica produção (51,9\% para as famílias precoces e $54,8 \%$ para as famílias de ciclo médio), e indicaram haver possibilidade de progresso com seleção para esta característica, bem como para brusone na panícula.

Em experimento conduzido com a população de arroz irrigado CNA 1, Rodriguez et al. (1998) avaliaram 97 famílias $\mathrm{S}_{0: 1}$ no campo experimental da Embrapa/CNPAF, Goianira (GO) no ano agrícola 1993/94 e obtiveram valores de herdabilidade para as características altura de plantas $(95,6 \%)$, dias para floração $(62,2 \%)$, peso de 100 grãos $(31,3 \%)$, produtividade $(85,2 \%)$, porcentagem de grãos cheios por panícula $(51,7 \%)$ e número de espiguetas por panícula $(49,3 \%)$. As estimativas de coeficiente de variação genética $\left(\mathrm{CV}_{\mathrm{g}}\right)$ apresentaram valores elevados para produtividade e altura. Para as características dias para floração e peso de 100 grãos essas estimativas apresentaram baixos valores e a explicação dada para isso são os próprios valores de variância genética obtidos na população, 
devido a constituição da população, que foi sintetizada utilizando materiais precoces. Os maiores valores de $\left(\mathrm{CV}_{\mathrm{g}} / \mathrm{CV}_{\mathrm{e}}\right)$ foram encontrados para as características altura e produção, indicando serem esses os caracteres mais favoráveis para a seleção. O autor ainda discute que a população apresenta-se bastante promissora para ser utilizada em programas de melhoramento.

Santos et al. (1997) conduziram um experimento com a população de arroz irrigado CNA-IRAT 4ME/1/1 em Lambari e Cambuquira (MG), com a finalidade de estimar parâmetros genéticos e fenotípicos da população. As características avaliadas foram altura de plantas, dias para floração, produção de grãos e incidência do patógeno Drechslera oryzae, causador da mancha parda e de Pyricularia grisea Jacc., causador de brusone. Os coeficientes de herdabilidade encontrados variaram conforme o local e o ano. Em Lambari, no ano agrícola 1992/93 foram obtidos valores de $64,9 \%$ e $47,7 \%$ para as características altura da planta e dias para floração; no ano seguinte esses valores foram para $32,7 \%$ e $65,5 \%$, respectivamente. Em Cambuquira, os valores de herdabilidade obtidos para altura de plantas e dias para floração foram de $70,6 \%$ e $69,0 \%$ para o experimento de 1993/94. Os autores discutem que ao estimar herdabilidade por diferentes métodos (herdabilidade no sentido amplo, regressão genitor-descendente e herdabilidade realizada) obtiveram maiores valores para herdabilidade no sentido amplo. Os coeficientes de variação genética $\left(\mathrm{CV}_{\mathrm{g}}\right)$ mais altos foram para a característica produção de grãos por planta, indicando poder haver seleção para esse caráter. Os coeficientes de variação ambiental $\left(\mathrm{CV}_{\mathrm{c}}\right)$ apresentados para produção de grãos (acima de 24\%) foram maiores do que os apresentados em experimentos similares, e a explicação para isso, dada pelos autores foi o pequeno tamanho da amostra utilizada.

A interpretação dos parâmetros genéticos permite que o melhorista faça escolhas mais adequadas em relação aos procedimentos a serem adotados, de manutenção ou não de uma população dentro do programa de melhoramento; de 
necessidade de ampliação da variabilidade da população através da realização de novos cruzamentos e da seleção mais ou menos intensiva para os diferentes caracteres dependendo do ciclo em que se encontra, etc.

Pesquisadores do Centro Internacional de Agricultura Tropical (CIAT, Colômbia) utilizando a Seleção Recorrente, têm observado e caracterizado as populações e os pools gênicos formados a partir de cruzamentos que utilizam a macho-esterilidade e têm intercambiado esses materiais com países da América Latina como Brasil, Argentina e Colômbia ou da África, como Costa do Marfím, Mali e Madagascar (CIAT ANNUAL REPORT, 1994). Utiliza-se parâmetros genéticos e fenotípicos para se indicar o potencial genético das populações. 


\section{MATERIAIS E MÉTODOS}

\subsection{Populações segregantes}

Foram avaliadas duas populações segregantes de arroz de sequeiro, derivadas de cruzamentos abertos realizados no programa de melhoramento genético de arroz do Centro Internacional de Agricultura Tropical (CIAT/Colômbia), a saber:

População CNA-IRAT A/0/2 $\left(\mathrm{P}_{0}\right)$, que consiste em uma população japônica para ecossistemas de sequeiro desenvolvida a partir do cruzamento de plantas macho-estéreis do pool gênico CNA-IRAT 5 com sete materiais precoces.

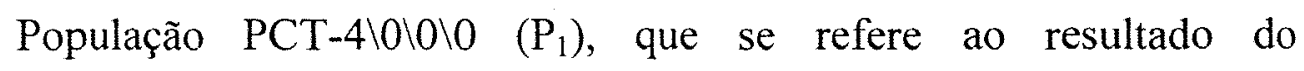
cruzamento da própria população $\mathrm{P}_{0}$ com sete linhagens: CT11231-2-2-1-4-M ( $\left.\mathrm{L}_{1}\right)$, CT11608-8-6-M-2-M (L $\left.\mathrm{L}_{2}\right)$, CT6196-33-11-1-3-M (L $\left.\mathrm{L}_{3}\right)$, A8-394 $\left(\mathrm{L}_{4}\right)$, IR-53167-3$M\left(L_{5}\right)$, CT11231-2-2-3-1-M ( $\left.\mathrm{L}_{6}\right)$ e CT11231-2-2-2-1-2-M ( $\left.\mathrm{L}_{7}\right)$, conforme descrito por Châtel e Guimarães (1995). As proporções genéticas de cada componente da população estão apresentadas na Tabela 1.

\subsection{Linhagens homozigóticas}

Foram avaliadas cinco linhagens homozigóticas, escolhidas por terem

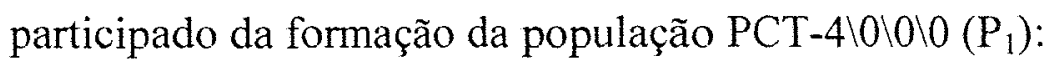

Linhagem CT11231-2-2-1-4-M (L $\left.\mathrm{L}_{1}\right)$, 
Linhagem CT11608-8-6-M-2-M ( $\left.\mathrm{L}_{2}\right)$,

Linhagem CT6196-33-11-1-3-M ( $\left.\mathrm{L}_{3}\right)$,

Linhagem A 8-394 $\left(\mathrm{L}_{4}\right) \mathrm{e}$

Linhagem IR 53167-3-M $\left(\mathrm{L}_{5}\right)$.

$L_{1}, L_{2}$ e $L_{3}$ foram obtidas do programa de melhoramento de arroz de sequeiro do $\mathrm{CIAT}, \mathrm{L}_{4}$ foi obtida do programa de melhoramento de arroz de sequeiro do CNPAF- EMBRAPA- BRASIL e $L_{5}$ foi obtida do International Rice Research Institute (IRRI), Filipinas. As características gerais das sete linhagens estão apresentadas na Tabela 2.

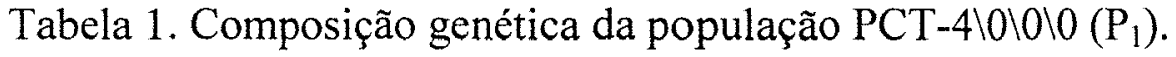

\begin{tabular}{|c|c|}
\hline Materiais usados no cruzamento & Participação (\%) \\
\hline CT11231-2-2-1-4-M $\left(\mathrm{L}_{1}\right)$ & 4,17 \\
\hline CT11608-8-6-M-2-M $\left(\mathrm{L}_{2}\right)$ & 8,33 \\
\hline CT6196-33-11-1-3-M $\left(\mathrm{L}_{3}\right)$ & 8,33 \\
\hline A8-394 $\left(\mathrm{L}_{4}\right)$ & 8,33 \\
\hline IR53167-3-M $\left(\mathrm{L}_{5}\right)$ & 8,33 \\
\hline CT11231-2-2-3-1-M (L $\left.{ }_{6}\right)$ & 4,17 \\
\hline CT11231-2-2-2-1-2-M (L $\left.\mathrm{L}_{7}\right)$ & 8,33 \\
\hline CNA-IRAT A $\left(\mathrm{P}_{0}\right)$ & 50,00 \\
\hline
\end{tabular}


Tabela 2. Características das sete linhagens avaliadas para a composição da

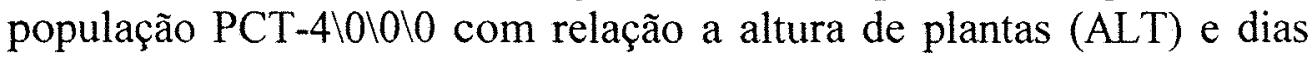
para floração (FLOR).

\begin{tabular}{|c|c|c|}
\hline \multirow{2}{*}{$\begin{array}{c}\text { Materiais utilizados no } \\
\text { cruzamento }\end{array}$} & \multicolumn{2}{|c|}{ Características ${ }^{1}$} \\
\hline & ALT & FLOR \\
\hline CT11231-2-2-1-4-M $\left(L_{1}\right)$ & 52 & 78 \\
\hline CT11608-8-6-M-2-M ( $\left.\mathrm{L}_{2}\right)$ & 78 & 78 \\
\hline CT6196-33-11-1-3-M $\left(\mathrm{L}_{3}\right)$ & 60 & 91 \\
\hline A8-394 $\left(\mathrm{L}_{4}\right)$ & 60 & 65 \\
\hline IR53167-3-M $\left(\mathrm{L}_{5}\right)$ & 59 & 69 \\
\hline CT11231-2-2-3-1-M (L6) & 57 & 78 \\
\hline $\mathrm{CT} 11231-2-2-2-1-2-\mathrm{M}\left(\mathrm{L}_{7}\right)$ & 50 & 78 \\
\hline
\end{tabular}

FONTE: Châtel et al., 1995. Avaliado na Estaçăo Experimental do CIAT, Palmira, Colômbia,

\subsection{Execução experimental}

O experimento foi conduzido no período de maio a setembro de 1995, na Estação Experimental "La Libertad" (EELL), localizada a 23 quilômetros do centro da cidade de Villavicencio, Meta, Colômbia (333m de altitude, 403'Lat. $\mathrm{N}$ e $73^{\circ} 04^{\prime}$ Long. O). $\mathrm{O}$ terreno foi preparado seguindo-se as práticas agronômicas recomendadas para as savanas colombianas, com incorporação de Crotalaria juncea no ano de 1994, e seguido de aração, gradeação e calagem antes de ser realizado o plantio, no ano de 1995 . Houve fertilização do terreno com $60 \mathrm{Kg} / \mathrm{ha}$ de $\mathrm{N}$ na forma de uréia; $60 \mathrm{Kg} / \mathrm{ha}$ de $\mathrm{P}$ na forma de superfosfato simples $\left(\mathrm{P}_{2} \mathrm{O}_{5}\right)$ e $60 \mathrm{Kg}$ ha de $\mathrm{K}$ na forma de $\mathrm{K}_{2} \mathrm{O}$. O controle de ervas daninhas foi feito aplicandoherbicidas pós-emergentes com os princípios ativos bentazon e propanil. Aos $15 \mathrm{e}$ 
30 dias foi feito o controle contra Brusone (Pyricularia griseas Sacc.) aplicando-se BIM + HINOSAN em pó (com os princípios ativos tricyclazone e edifephos). O delineamento experimental utilizado foi o de blocos casualizados com quatro repetições. Em cada repetição foram alocadas sete parcelas, sendo que cinco delas continham as linhagens e as outras duas continham as populações. As parcelas com linhagens possuíam quatro linhas de $5 \mathrm{~m}$ de comprimento, enquanto aquelas parcelas com populações possuíam 12 linhas de mesmo tamanho. $\mathrm{O}$ espaçamento entre linhas e entre plantas era de $30 \mathrm{~cm}$. Cada linha continha 16 plantas,

totalizando 64 plantas/parcela/repetição para as linhagens e 192 plantas/parcela/repetição para as populações. $O$ experimento foi circundado por três fileiras de milho, com o intuito de impedir a entrada de pólens migrantes.

\subsection{Avaliações}

Foram tomadas aleatoriamente em cada uma das repetições 20 plantas de cada um dos tratamentos com linhagens, e 100 plantas dos tratamentos com as populações segregantes, para avaliar sete características agronômicas, a saber:

Altura da planta (ALT): Distância, em centímetros, do solo ao ápice da panícula, medida na época de maturação.

Dias para floração (FLOR): Número de dias decorridos do plantio até o florescimento médio.

Número de perfilhos por planta (NPERF): Número de perfilhos por planta na fase de início do florescimento.

Número de panículas por planta (NPAN): Número de panículas por planta na época de maturação. 
Fertilidade: Verificação e contagem se as plantas são férteis ou estéreis pela coloração da antera. As anteras de coloração branca apresentam macho-esterilidade, enquanto que as férteis apresentam coloração amarelada.

Produção de grãos por planta (PROD): Depois de coletadas todas as panículas de cada planta, elas foram debulhadas e pesadas, em gramas. Essa variável foi subdividida em duas, baseando-se no comportamento da planta com relação ao caráter fertilidade. A produção de grãos por plantas férteis passou a receber a denominação PRODF, e das plantas macho-estéreis, a denominação PRODMS.

Desta maneira, foram criadas as variáveis: produção de grãos por plantas férteis (PRODF): peso, em gramas, dos grãos de todas as panículas da planta, considerando-se apenas as panículas inteiramente férteis, e produção de grãos por plantas macho-estéreis (PRODMS): peso, em gramas, de todos os grãos cheios de todas as panículas da planta, considerando as panículas macho-estéreis.

Peso de 100 grãos $\left(\mathrm{P}_{100}\right)$ : Peso de 100 grãos em gramas.

\subsection{Procedimentos estatístico-genéticos}

\subsubsection{Comparação entre as populações e linhagens quanto à média}

Foram analisados estatisticamente os dados originais das populações $\mathrm{P}_{0}$ e $\mathrm{P}_{1}$ e das linhagens $\mathrm{L}_{1}$ a $\mathrm{L}_{5}$ para as características ALT, FLOR, NPERF, NPAN, PROD, PRODF, PRODMS e $\mathrm{P}_{100}$. Para cada caráter avaliado das populações $\mathrm{P}_{0} \mathrm{e}$ $\mathrm{P}_{1}$ foram calculadas as médias dos tratamentos em cada repetição conforme esquema mostrado na Tabela 3. 
Tabela 3. Valores de média de cada população e linhagem, em cada repetição.

\begin{tabular}{|c|c|c|c|c|}
\hline População & Rep. I & Rep. II & Rep. III & Rep. IV \\
\hline$P_{0}$ & Média $P_{0, I}$ & Média $P_{0, I I}$ & Média $P_{0, \mathrm{III}}$ & Média $P_{0,1 V}$ \\
\hline$P_{1}$ & Média $P_{1,1}$ & Média $P_{1, \text { II }}$ & Média $P_{1, \text { III }}$ & Média $P_{1, I V}$ \\
\hline$L_{1}$ & Média $L_{1,1}$ & Média $L_{1, \text { II }}$ & Média $L_{1, \text { III }}$ & Média $L_{1, I V}$ \\
\hline $\mathrm{L}_{2}$ & Média $L_{2, I}$ & Média $L_{2, \text { II }}$ & Média $L_{2, \text { III }}$ & Média $L_{2, \text { IV }}$ \\
\hline $\mathrm{L}_{3}$ & Média $L_{3, \mathrm{I}}$ & Média $L_{3, \mathrm{II}}$ & Média $L_{3, \text { III }}$ & Média $L_{3, \text { IV }}$ \\
\hline $\mathrm{L}_{4}$ & Média $\mathrm{L}_{4,1}$ & Média $L_{4, \text { II }}$ & Média $L_{4, \text { III }}$ & Média L4, IV \\
\hline $\mathrm{L}_{5}$ & Média $L_{5, \mathrm{I}}$ & Média $L_{5, \text { II }}$ & Média $L_{5, \text { III }}$ & Média $L_{5, \text { IV }}$ \\
\hline
\end{tabular}

Para as características PRODF e PRODMS, foram apresentados os valores de médias das populações apenas, pelo fato das plantas poderem ser separadas entre férteis e macho-estéreis enquanto que as linhagens apresentam apenas plantas férteis.

Para análise de variância da média foi adotado o esquema experimental com base no modelo de blocos casualizados, conforme apresentado na Tabela 4 (Pimentel Gomes, 1990). Para as características PRODF e PRODMS a análise de variância seguiu o modelo descrito na Tabela 4 entretanto; sem ser feito o desdobramento, uma vez que o número total de tratamentos era de apenas dois. A comparação entre a média das linhagens foi feita com base no teste de Tukey. 
Tabela 4. Análise de variância com base nas médias dos tratamentos.

\begin{tabular}{lccc}
\hline \multicolumn{1}{c}{ F.V. } & G.L. & Q.M. & F \\
\hline Repetições & $\mathrm{r}-1$ & $\mathrm{Q}_{6}$ & $\mathrm{Q}_{6} / \mathrm{Q}_{1}$ \\
Tratamentos & $\mathrm{t}-1$ & $\mathrm{Q}_{5}$ & $\mathrm{Q}_{5} / \mathrm{Q}_{1}$ \\
Pop vs Lin & $\mathrm{s}-1$ & $\mathrm{Q}_{4}$ & $\mathrm{Q}_{4} / \mathrm{Q}_{1}$ \\
Lin & $\mathrm{l}-1$ & $\mathrm{Q}_{3}$ & $\mathrm{Q}_{3} / \mathrm{Q}_{1}$ \\
$\mathrm{P}_{0}$ vs $\mathrm{P}_{1}$ & $\mathrm{p}-1$ & $\mathrm{Q}_{2}$ & $\mathrm{Q}_{2} / \mathrm{Q}_{1}$ \\
Erro & $(\mathrm{r}-1)(\mathrm{t}-1)$ & $\mathrm{Q}_{1}$ & - \\
\hline Total & $\mathrm{rt}-1$ & & \\
\hline
\end{tabular}

onde,

r é o número de repetições,

t é o número de tratamentos,

$\mathrm{s}$ é o número de grupos,

1 é o número de tratamentos com linhagens,

$\mathrm{p}$ é o número de tratamentos com populações,

$\mathrm{Q}_{1}$ é o quadrado médio do erro,

$\mathrm{Q}_{2}$ é o quadrado médio das populações,

$\mathrm{Q}_{3}$ é quadrado médio das linhagens,

$\mathrm{Q}_{4}$ é o quadrado médio dos grupos,

$\mathrm{Q}_{5}$ é o quadrado médio dos tratamentos e

$\mathrm{Q}_{6}$ é o quadrado médio das repetições. 


\subsubsection{Comparação entre as populações quanto à variância}

Foram calculadas as variâncias de cada uma das repetições a partir dos dados originais das populações $P_{0}$ e $P_{1}$ para as características altura (ALT), dias para floração (FLOR), número de perfilhos por planta (NPERF), número de panículas por planta (NPAN), produção de grãos por planta (PROD), produção de grãos de plantas férteis (PRODF), produção de grãos de plantas macho-estéreis (PRODMS), peso de 100 grãos $\left(\mathrm{P}_{100}\right)$ conforme apresentado na Tabela 5.

Tabela 5. Valores de variância de cada população, em cada repetição.

\begin{tabular}{|c|c|c|c|c|}
\hline População & Rep. I & Rep. II & Rep. III & Rep. IV \\
\hline$P_{0}$ & $V P_{0,1}$ & $\mathrm{VP}_{0,1 \mathrm{II}}$ & $V P_{0, I I I}$ & $V P_{0, I V}$ \\
\hline$P_{1}$ & $V P_{1,1}$ & $V P_{1, \text { II }}$ & $V P_{1, \mathrm{III}}$ & $\mathrm{VP}_{1, \mathrm{IV}}$ \\
\hline
\end{tabular}

Em seguida, os dados foram transformados pela escala logarítmica para todas as características, com exceção de peso de 100 grãos, que foi multiplicado por mil antes de se fazer transformação. Foi feita uma análise de variância da variância adotando-se o esquema experimental com base no modelo de blocos casualizados, conforme Tabela 6 (Pimentel Gomes, 1990).

Tabela 6. Análise de variância das variâncias dos tratamentos, com dados transformados pela escala logarítmica.

\begin{tabular}{lccc}
\hline F.V. & G.L. & Q.M. & F \\
Repetições & $\mathrm{r}-1$ & $\mathrm{Q}_{3}$ & $\mathrm{Q}_{3} / \mathrm{Q}_{1}$ \\
Tratamentos & $\mathrm{t}-1$ & $\mathrm{Q}_{2}$ & $\mathrm{Q}_{2} / \mathrm{Q}_{1}$ \\
Erro & $(\mathrm{r}-1)(\mathrm{t}-1)$ & $\mathrm{Q}_{1}$ & \\
\hline Total & $\mathrm{rt}-1$ & & \\
\hline
\end{tabular}


onde,

r é o número de repetições,

t é o número de tratamentos,

$\mathrm{Q}_{1}$ é o quadrado médio do erro,

$\mathrm{Q}_{2}$ é o quadrado médio dos tratamentos e

$\mathrm{Q}_{3}$ é o quadrado médio das repetições.

\subsubsection{Análises de variância dentro de populações}

Para se estimar a magnitude da variância genética das duas populações, considerou-se que a média da variância existente dentro das linhagens (homozigóticas) representaria a variância ambiental presente no experimento para cada característica avaliada. Para isso, utilizou-se os modelos descritos nas Tabelas 7 a 9. Nessas tabelas considerou-se o estande ideal para cada tratamento, isto é, 100 plantas para as populações e 20 plantas para as linhagens. Inicialmente foram calculadas as variâncias de cada tratamento por repetição (Tabela 7). Em seguida, os tratamentos L (linhagens) foram unidos em uma única classe, estimando-se a média ponderada entre as variâncias das linhagens (Tabela 8). Finalmente, uniu-se as quatro repetições na forma hierárquica, extrapolando os resultados para todo o experimento (Tabela 9). 
Tabela 7. Análise de variância, considerando cada população e linhagem separadamente, para cada repetição.

\begin{tabular}{ccc}
\hline F.V. & G.L. & E(Q.M.) \\
\hline Entre plantas/ $\mathrm{P}_{0}$ & 99 & $\sigma_{e}^{2}+\sigma_{g P_{\mathrm{v}}}^{2}$ \\
Entre plantas/ $\mathrm{P}_{1}$ & 99 & $\sigma_{e}^{2}+\sigma_{g P_{1}}^{2}$ \\
Entre plantas/ $\mathrm{L}_{1}$ & 19 & $\sigma_{e}^{2}$ \\
Entre plantas/ $\mathrm{L}_{2}$ & 19 & $\sigma_{e}^{2}$ \\
Entre plantas/ $\mathrm{L}_{3}$ & 19 & $\sigma_{e}^{2}$ \\
Entre plantas/ $\mathrm{L}_{4}$ & 19 & $\sigma_{e}^{2}$ \\
Entre plantas/ $\mathrm{L}_{5}$ & 19 & $\sigma_{e}^{2}$ \\
\hline
\end{tabular}

Tabela 8. Análise de variância para cada repetição, unindo as linhagens em um único tratamento.

\begin{tabular}{ccc}
\hline F.V. & G.L. & E(Q.M.) \\
\hline Entre plantas/ $P_{0}$ & 99 & $\sigma_{e}^{2}+\sigma_{g P_{0}}^{2}$ \\
Entre plantas/ $P_{1}$ & 99 & $\sigma_{e}^{2}+\sigma_{g_{P_{1}}}^{2}$ \\
Entre plantas/L & 95 & $\sigma_{e}^{2}$ \\
\hline
\end{tabular}


Tabela 9. Análise de variância, considerando-se as quatro repetições, unindo as linhagens em um único tratamento.

\begin{tabular}{cccc}
\hline F.V. & G.L. & QM & E(Q.M.) \\
\hline Entre plantas/ $\mathrm{P}_{0} / \mathrm{R}$ & 396 & $\mathrm{Q}_{3}$ & $\sigma_{e}^{2}+\sigma_{g P_{0}}^{2}$ \\
Entre plantas/ $/ \mathrm{P}_{1} / \mathrm{R}$ & 396 & $\mathrm{Q}_{2}$ & $\sigma_{e}^{2}+\sigma_{g P_{1}}^{2}$ \\
Entre plantas/L /R & 380 & $\mathrm{Q}_{1}$ & $\sigma_{e}^{2}$ \\
\hline
\end{tabular}

onde,

$\sigma_{g P_{0}}^{2}$ é a variância genética da população $\mathrm{P}_{0}$,

$\sigma_{g_{1}}^{2}$ é a variância genética da população $\mathrm{P}_{1} \mathrm{e}$

$\sigma_{e}^{2}$ é a variância ambiental.

\subsubsection{Estimativas de parâmetros genéticos e fenotípicos}

Foram estimadas as variâncias genética e ambiental para cada um dos caracteres avaliados, de acordo com as seguintes expressões, a partir da Tabela 9:

Variância ambiental $\left(\sigma_{e}^{2}\right)$ :

$\hat{\sigma}_{e}^{2}=Q_{1}$ 
Variância genética de $\mathrm{P}_{0}\left(\sigma_{g_{0}^{P_{0}}}^{2}\right)$ :

$\hat{\sigma}_{g P_{0}}^{2}=Q_{3}-Q_{1}$

Variância genética de $\mathrm{P}_{1}\left(\sigma_{g_{1}}^{2}\right)$ :

$\hat{\sigma}_{g P_{1}}^{2}=Q_{2}-Q_{1}$

Coeficiente de variação genético de $\mathrm{P}_{0}\left(C V_{g P_{0}}\right)$ :

$C V_{g P_{0}} \%=\frac{\sqrt{\hat{\sigma}_{g P_{0}}^{2}}}{\bar{X}_{P_{0}}} \times 100$

Coeficiente de variação genético de $\mathrm{P}_{1}\left(C V_{g P_{1}}\right)$ :

$C V_{g_{p_{1}}} \%=\frac{\sqrt{\hat{\sigma}_{g_{P_{1}}}^{2}}}{\bar{X}_{P_{1}}} \times 100$

Coeficiente de variação experimental $\left(C V_{e}\right)$ :

$C V_{e} \%=\frac{\sqrt{\hat{\sigma}_{e}^{2}}}{\bar{X}} \times 100$ 
Coeficiente b para $\mathrm{P}_{0}\left(b_{P_{0}}\right)$ :

$\hat{b}_{P_{0}}=\frac{C V_{g_{P_{0}}}}{C V_{e}}$

Coeficiente b para $\mathrm{P}_{1}\left(b_{P_{1}}\right)$ :

$\hat{b}_{P_{1}}=\frac{C V_{g P_{1}}}{C V_{e}}$

Coeficiente de herdabilidade de $\mathrm{P}_{0}\left(h_{P_{0}}^{2} \%\right)$ :

$\hat{h}_{P_{0}}^{2} \%=\frac{\hat{\sigma}_{g_{P_{0}}}^{2}}{\sigma_{g_{\rho_{0}}}^{2}+\hat{\sigma}_{e}^{2}} \times 100$

Coeficiente de herdabilidade de $\mathrm{P}_{1}\left(h_{P_{1}}^{2} \%\right)$ :

$\hat{h}_{P_{1}}^{2} \%=\frac{\hat{\sigma}_{g_{p_{1}}}^{2}}{\hat{\sigma}_{g_{p_{1}}}^{2}+\hat{\sigma}_{e}^{2}} \times 100$ 


\section{RESULTADOS E DISCUSSÃO}

\subsection{Comparação entre linhagens e populações segregantes em termos de média}

Na Tabela 10 os valores das médias das linhagens $L_{1}$ a $L_{5}$ e das populações $\mathrm{P}_{0}$ e $\mathrm{P}_{1}$, obtidos por repetição, são apresentados para as características ALT, FLOR, NPERF, NPAN, PROD e $\mathrm{P}_{100}$. Na Tabela 11 são apresentados os dados das populações $\mathrm{P}_{0}$ e $\mathrm{P}_{1}$ por repetição para PRODF e PRODMS.

Os resultados das análises de variância com base nas médias das linhagens e populações são apresentados nas Tabelas 12 e 13 para as características ALT, FLOR, NPERF, NPAN, PROD e $\mathrm{P}_{100}$. Na Tabela 14 são encontradas as análises de variância para as características PRODF e PRODMS, onde se considerou apenas as populações como tratamentos.

Com relação aos coeficientes de variação experimental, as características NPERF, NPAN, PROD, PRODF e PRODMS (Tabelas 12, 13 e 14) apresentaram os valores mais altos e isso indica que estão mais sujeitas a erros experimentais por serem mais sensíveis à variação ambiental (Jennings et al., 1985). As análises de variância (Tabelas 12, 13 e 14) permitem verificar que não houve diferença estatisticamente significativa entre repetições para quaisquer das características avaliadas. 
Tabela 10. Valores médios das caracteristicas altura de planta (ALT), dias para floração (FLOR), número de perfilhos por planta (NPERF), número de panículas por planta (NPAN), produção de grãos por planta (PROD) e peso de 100 grãos $\left(\mathrm{P}_{100}\right)$ das populações $\mathrm{P}_{0}$ e $\mathrm{P}_{1}$ e das linhagens $\mathrm{L}_{1}$ a $\mathrm{L}_{5}$, nas quatro repetições.

\begin{tabular}{|c|c|c|c|c|c|}
\hline Características & & Rep. I & Rep. II & Rep. III & Rep. IV \\
\hline \multirow{7}{*}{$\operatorname{ALT}(\mathrm{cm})$} & $\mathrm{L}_{\mathrm{I}}$ & 86,45 & 91,40 & 90,48 & 92,87 \\
\hline & $\mathrm{L}_{2}$ & 104,70 & 106,35 & 102,05 & 103,95 \\
\hline & $\mathrm{L}_{3}$ & 73,60 & 77,85 & 75,90 & 77,40 \\
\hline & $\mathrm{L}_{4}$ & 106,90 & 111,00 & 113,40 & 94,65 \\
\hline & $\mathrm{L}_{5}$ & 100,20 & 103,85 & 100,74 & 99,75 \\
\hline & $\mathrm{P}_{0}$ & 109,02 & 110,57 & 109,47 & 110,25 \\
\hline & $P_{1}$ & 100,62 & 104,33 & 103,14 & 101,39 \\
\hline \multirow{7}{*}{ FLOR (dias) } & $\mathrm{L}_{1}$ & 67,45 & 66,50 & 66,76 & 67,52 \\
\hline & $\mathrm{L}_{2}$ & 80,35 & 79,30 & 80,43 & 81,20 \\
\hline & $\mathrm{L}_{3}$ & 81,20 & 79,75 & 80,75 & 81,70 \\
\hline & $\mathrm{L}_{4}$ & 92,15 & 92,80 & 89,95 & 88,15 \\
\hline & $\mathrm{L}_{5}$ & 72,95 & 74,40 & 75,87 & 77,10 \\
\hline & $\mathrm{P}_{0}$ & 74,56 & 74,87 & 78,92 & 75,98 \\
\hline & $P_{1}$ & 79,38 & 77,57 & 78,07 & 82,54 \\
\hline \multirow{7}{*}{ NPERF (por planta) } & $\mathrm{L}_{1}$ & 9,80 & 10,95 & 12,62 & 12,96 \\
\hline & $\mathrm{L}_{2}$ & 16,60 & 17,85 & 18,38 & 16,50 \\
\hline & $\mathrm{L}_{3}$ & 16,00 & 17,25 & 15,85 & 17,79 \\
\hline & $\mathrm{L}_{4}$ & 16,90 & 22,80 & 19,35 & 9,85 \\
\hline & $\mathrm{L}_{5}$ & 8,60 & 11,75 & 12,00 & 11,60 \\
\hline & $P_{0}$ & 12,05 & 12,70 & 13,89 & 13,14 \\
\hline & $P_{1}$ & 15,79 & 16,05 & 19,87 & 17,37 \\
\hline \multirow{7}{*}{ NPAN (por planta) } & $\mathrm{L}_{1}$ & 9,85 & 10,83 & 12,71 & 12,88 \\
\hline & $\mathrm{L}_{2}$ & 15,77 & 17,36 & 18,27 & 15,95 \\
\hline & $\mathrm{L}_{3}$ & 16,57 & 18,73 & 15,65 & 19,00 \\
\hline & $\mathrm{L}_{4}$ & 18,05 & 23,30 & 19,30 & 10,50 \\
\hline & $\mathrm{L}_{5}$ & 9,48 & 12,71 & 13,65 & 10,70 \\
\hline & $P_{0}$ & 10,75 & 12,06 & 12,69 & 12,33 \\
\hline & $P_{1}$ & 14,31 & 14,13 & 17,61 & 15,83 \\
\hline \multirow{7}{*}{ PROD $^{1}$ (grãos em g/ planta) } & $\mathrm{L}_{1}$ & 21,95 & 29,54 & 28,39 & 32,87 \\
\hline & $\mathrm{L}_{2}$ & 29,53 & 34,21 & 34,48 & 26,82 \\
\hline & $\mathrm{L}_{3}$ & 17,35 & 26,65 & 19,60 & 21,76 \\
\hline & $\mathrm{L}_{4}$ & 20,33 & 22,50 & 41,97 & 9,99 \\
\hline & $\mathrm{L}_{5}$ & 25,14 & 39,02 & 33,85 & 27,53 \\
\hline & $P_{0}$ & 27,58 & 35,14 & 31,09 & 37,45 \\
\hline & $\mathrm{P}_{1}$ & 23,46 & 24,23 & 29,43 & 24,74 \\
\hline \multirow{7}{*}{$P_{100}$ (gramas) } & $\mathrm{L}_{1}$ & 3,32 & 3,40 & 3,45 & 3,50 \\
\hline & $\mathrm{L}_{2}$ & 2,55 & 2,62 & 2,63 & 2,60 \\
\hline & $\mathrm{L}_{3}$ & 2,21 & 2,24 & 2,38 & 2,30 \\
\hline & $\mathrm{L}_{4}$ & 2,52 & 2,48 & 2,61 & 2,34 \\
\hline & $\mathrm{L}_{\mathrm{s}}$ & 3,43 & 3,43 & 3,37 & 3,46 \\
\hline & $P_{0}$ & 3,43 & 3,53 & 3,37 & 3,46 \\
\hline & $P_{1}$ & 3,03 & 3,08 & 3,11 & 3,06 \\
\hline
\end{tabular}

${ }^{1}$ Considerando-se as plantas férteis e macho-estereis das populações. 
Tabela 11. Valores de média das características produção de grãos de plantas férteis (PRODF), produção de grãos de plantas macho-estéreis (PRODMS) das populações $\mathrm{P}_{0}$ e $\mathrm{P}_{1}$ nas quatro repetições.

\begin{tabular}{clrrrr}
\hline Características & & Rep. I & Rep. II & Rep. III & Rep. IV \\
\hline \multirow{2}{*}{ PRODF (grãos em g/ planta) } & $\mathrm{P}_{0}$ & 35,48 & 43,32 & 37,59 & 45,39 \\
& $\mathrm{P}_{1}$ & 32,75 & 31,80 & 40,60 & 29,81 \\
PRODMS (grãos em g/ planta) & $\mathrm{P}_{0}$ & 12,76 & 20,89 & 16,04 & 21,55 \\
& $\mathrm{P}_{1}$ & 13,20 & 14,23 & 16,57 & 18,32 \\
\hline
\end{tabular}

Tabela 12. Fontes de variação (FV), graus de liberdade (GL) e quadrados médios (QM) para a análise de variância da média dos caracteres altura de planta (ALT), dias para floração (FLOR) e número de perfilhos por planta (NPERF) das linhagens $L_{1}$ a $L_{5}$ e populações $P_{0}$ e $P_{1}$.

\begin{tabular}{|c|c|c|c|c|}
\hline & & $\underset{(\mathrm{cm})}{\mathrm{ALT}}$ & $\underset{\text { (dias) }}{\text { FLOR }}$ & $\begin{array}{l}\text { NPERF } \\
\text { (por planta) }\end{array}$ \\
\hline FV & GL & $\mathbf{Q M}$ & QM & $\mathbf{Q M}$ \\
\hline Repetições & 3 & $20,402^{\text {ns }}$ & $2,108^{\text {ns }}$ & $8,721^{\text {ns }}$ \\
\hline Tratamentos & 6 & $541,442^{* *}$ & $205,645^{* *}$ & $33,592^{* *}$ \\
\hline P vs $L$ & 1 & $620,943^{* *}$ & $6,637^{\mathrm{ns}}$ & $0,651^{\mathrm{ns}}$ \\
\hline Lin & 4 & $629,120^{* *}$ & $301,338^{* *}$ & $40,873^{* *}$ \\
\hline$P_{0}$ vs $P_{1}$ & 1 & $111,229^{* *}$ & $21,879^{*}$ & $37,411^{*}$ \\
\hline Erro & 18 & 11,708 & 2,691 & 5,317 \\
\hline $\mathrm{CV} \%$ & & 3,47 & 2,09 & 15,51 \\
\hline Média & & 98,65 & 78,51 & 14,87 \\
\hline
\end{tabular}


Tabela 13. Fontes de variação (FV), graus de liberdade (GL) e quadrados médios (QM) para a análise de variância da média dos caracteres número de panículas por planta (NPAN), produção de grãos por planta (PROD) e peso de 100 grãos $\left(\mathrm{P}_{100}\right)$ das linhagens $\mathrm{L}_{1}$ a $\mathrm{L}_{5}$ e populações $\mathrm{P}_{0}$ e $\mathrm{P}_{1}$.

\begin{tabular}{|c|c|c|c|c|}
\hline & & $\underset{\text { (por planta) }}{\text { NPAN }}$ & $\underset{\text { (grấos em g/planta) }}{\mathrm{PROD}^{1}}$ & $\underset{\text { (gramas) }}{P_{100}}$ \\
\hline FV & GL & $\mathbf{Q M}$ & $\mathbf{Q M}$ & $\mathbf{Q M}$ \\
\hline Repetições & 3 & $8,850^{\mathrm{ns}}$ & $90,50721^{\mathrm{ns}}$ & $0,00458^{\text {ns }}$ \\
\hline Tratamentos & 6 & $32,793^{* *}$ & $76,07307^{\mathrm{ns}}$ & $0,98988^{* *}$ \\
\hline P vs $L$ & 1 & $10,403^{\mathrm{ns}}$ & $22,08603^{\mathrm{ns}}$ & $0,99137^{* *}$ \\
\hline Lin & 4 & $40,419^{* *}$ & $81,57671^{\mathrm{ns}}$ & $1,16545^{* *}$ \\
\hline $\mathrm{P}_{0}$ vs $\mathrm{P}_{1}$ & 1 & $24,675^{*}$ & $108,04514^{\mathrm{ns}}$ & $0,28501^{* *}$ \\
\hline Erro & 18 & 5,492 & 34,00692 & 0,00463 \\
\hline $\mathrm{CV} \%$ & & 15,96 & 21,02 & 2,30 \\
\hline Média & & 14,68 & 2,96 & 2,96 \\
\hline
\end{tabular}

Considerou-se as plantas férteis e as macho-estéreis da população $;{ }^{2}$ Considerou-se apenas as plantas férteis da população.

Tabela 14. Fontes de variação (FV), graus de liberdade (GL) e quadrados médios (QM) para a análise de variância da média dos caracteres produção de grãos de plantas férteis (PRODF) e produção de grãos de plantas macho-estéreis (PRODMS) das populações $\mathrm{P}_{0}$ e $\mathrm{P}_{1}$.

\begin{tabular}{lccc}
\hline \multicolumn{1}{c}{ FV } & GL & $\begin{array}{c}\text { PRODF }^{1} \\
\text { (grăos em g/planta) }\end{array}$ & $\begin{array}{c}\text { PRODMS }^{2} \\
\text { (grãos em g/planta) }\end{array}$ \\
\hline Repetições & 3 & QM & QM \\
Tratamentos & 1 & $8,901^{\text {ns }}$ & $16,799^{\text {ns }}$ \\
Erro & 3 & $89,914^{\text {ns }}$ & $9,946^{\text {ns }}$ \\
\hline CV\% & & 35,352 & 5,895 \\
Média & & 16,03 & 14,54 \\
\hline
\end{tabular}

Considerou-se apenas as populações como tratamentos. 
Entretanto, ao se comparar os tratamentos (Tabelas 12, 13 e 14) verifica-se que houve diferença estatisticamente significativa para as características ALT, FLOR, NPERF, NPAN e $P_{100}$.

A comparação entre grupos, ou seja, entre linhagens e populações, apresentou diferença estatisticamente significativa para as características ALT e $P_{100}$. Para as demais caracteristicas eles não diferiram entre si. Ao se comparar apenas as linhagens, verifica-se que elas diferiram estatisticamente entre si para as características ALT, FLOR, NPERF, NPAN e $\mathrm{P}_{100}$.

Observando a Tabela 14 nota-se que não houve diferença significativa entre tratamentos ou repetições para as características PRODF e PRODMS, como comentado anteriormente, entretanto, existe uma grande diferença entre as médias das duas características. Pode-se perceber que as plantas férteis pesam aproximadamente o dobro das plantas macho-estéreis dentro de populações $(37,09$ e $16,69 \mathrm{~g}$, respectivamente).

$\mathrm{Na}$ Tabela 15 são apresentados os valores de média originais para as populações $\mathrm{P}_{0}$ e $\mathrm{P}_{1}$ para todas as características avaliadas.

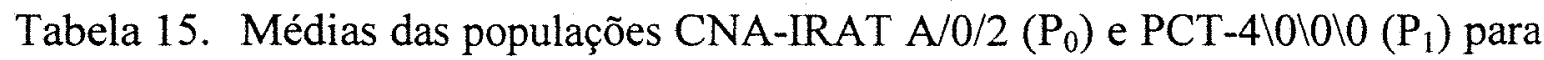
as características altura de planta (ALT), dias para floração (FLOR), número de perfilhos por planta (NPERF), número de panículas por planta (NPAN), produção de grãos por planta (PROD), produção de grãos de plantas férteis (PRODF), produção de grãos de plantas macho-estéreis (PRODMS), peso de 100 grãos $\left(\mathrm{P}_{100}\right)$.

\begin{tabular}{lcc}
\hline \multicolumn{1}{c}{ Características } & Média $^{\mathbf{1}} \mathbf{P}_{\mathbf{0}}$ & Média $^{\mathbf{1}} \mathbf{P}_{\mathbf{1}}$ \\
\hline ALT (cm) & $109,82^{\mathrm{a}}$ & $102,33^{\mathrm{b}}$ \\
FLOR (dias) & $76,00^{\mathrm{a}}$ & $79,38^{\mathrm{b}}$ \\
NPERF (por planta) & $12,91^{\mathrm{a}}$ & $17,25^{\mathrm{b}}$ \\
NPAN (por planta) & $11,89^{\mathrm{a}}$ & $15,40^{\mathrm{b}}$ \\
PROD (grãos em g/planta) & $32,46^{\mathrm{a}}$ & $25,38^{\mathrm{a}}$ \\
PRODF (grãos em g/planta) & $40,24^{\mathrm{a}}$ & $33,45^{\mathrm{a}}$ \\
PRODMS (grãos em g/planta) & $17,71^{\mathrm{a}}$ & $15,62^{\mathrm{a}}$ \\
P100 (gramas) & $3,45^{\mathrm{b}}$ & $3,07^{\mathrm{a}}$ \\
\hline
\end{tabular}


A observação da Tabela 15 permite perceber que houve diferença estatisticamente significativa entre as populações $\mathrm{P}_{0}$ e $\mathrm{P}_{1}$ com relação à média para os caracteres ALT, FLOR, NPERF, NPAN e $\mathrm{P}_{100}$, sendo que para a primeira e a última características houve diminuição do valor em $\mathrm{P}_{1}$ e para as demais houve aumento. Para os caracteres PROD, PRODF e PRODMS, embora a população $\mathrm{P}_{0}$ tenha sempre apresentado valores maiores que de $P_{1}$, essa diferença não era estatisticamente diferente.

Comparando a característica produção em plantas férteis e estéreis (PRODF e PRODMS) dentro de cada uma das populações verifica-se que tanto para $\mathrm{P}_{0}$ quanto para $\mathrm{P}_{1}$, as plantas férteis sempre apresentaram maiores valores (Tabela 15). Isso ocorre porque nas panículas macho-estéreis nem todas as flores são fecundadas, gerando grãos vazios.

$\mathrm{Na}$ Tabela 16 são apresentadas as médias das linhagens utilizadas como parentais para as características ALT, FLOR, NPERF, NPAN, PROD e $\mathrm{P}_{100}$ com o resultado do teste de Tukey.

Tabela 16. Valores médios das características altura de planta (ALT), dias para floração (FLOR), número de perfilhos por planta (NPERF), número de panículas por planta (NPAN), produção de grãos por planta (PROD) e peso de 100 grãos $\left(\mathrm{P}_{100}\right)$ para os materiais homozigotos (linhagens)

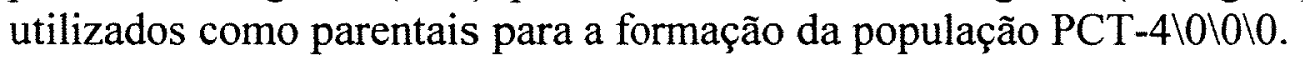

\begin{tabular}{c|rcclll}
\hline TRAT. & \multicolumn{1}{|c}{ ALT } & FLOR & NPERF & NPAN & PROD & P $_{100}$ \\
\hline $\mathbf{L}_{1}$ & $90,30^{\mathrm{b}}$ & $67,06^{\mathrm{d}}$ & $11,58^{\mathrm{a}, \mathrm{b}}$ & $11,57^{\mathrm{b}}$ & $28,18^{\mathrm{a}}$ & $3,42^{\mathrm{a}}$ \\
$\mathbf{L}_{2}$ & $104,26^{\mathrm{a}}$ & $80,32^{\mathrm{b}}$ & $17,33^{\mathrm{a}}$ & $16,84^{\mathrm{a}, \mathrm{b}}$ & $31,26^{\mathrm{a}}$ & $2,60^{\mathrm{b}}$ \\
$\mathbf{L}_{3}$ & $76,19^{\mathrm{c}}$ & $80,85^{\mathrm{b}}$ & $16,72^{\mathrm{a}, \mathrm{b}}$ & $17,48^{\mathrm{a}} \mathrm{b}$ & $21,34^{\mathrm{a}}$ & $2,28^{\mathrm{b}}$ \\
$\mathbf{L}_{4}$ & $106,49^{\mathrm{a}}$ & $90,76^{\mathrm{a}}$ & $17,22^{\mathrm{a}}$ & $17,79^{\mathrm{a}}$ & $23,69^{\mathrm{a}}$ & $2,49^{\mathrm{b}}$ \\
$\mathbf{L}_{5}$ & $101,13^{\mathrm{a}}$ & $75,08^{\mathrm{c}}$ & $10,98^{\mathrm{b}}$ & $11,64^{\mathrm{b}}$ & $31,38^{\mathrm{a}}$ & $3,17^{\mathrm{a}}$ \\
\hline
\end{tabular}

Verifica-se que apenas a característica PROD não apresentou diferença significativa entre os tratamentos. As características ALT e FLOR apresentaram maior número de materiais divergentes entre si, e NPERF, NPAN e $\mathrm{P}_{100}$ apresentam os materiais dispostos em apenas duas classes, mesmo assim, a grande 
divergência entre as classes caracteriza a possibilidade desses materiais terem gerado variabilidade ao serem cruzados com a população $\mathrm{P}_{0}$ (Tabela 16).

\subsection{Comparação entre populações segregantes em termos de variância}

Na Tabela 17 são apresentados os valores de variância obtidos por repetição para as populações $\mathrm{P}_{0}$ e $\mathrm{P}_{1}$, para todas as características avaliadas.

Tabela 17. Valores de variância das características altura de planta (ALT), dias para floração (FLOR), número de perfilhos por planta (NPERF), número de panículas por planta (NPAN), produção de grãos por planta (PROD), produção de grãos de plantas férteis (PRODF), produção de grãos de plantas macho-estéreis (PRODMS), peso de 100 grãos $\left(\mathrm{P}_{100}\right)$

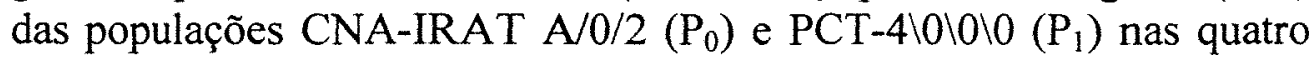
repetições.

\begin{tabular}{lcrrrr}
\hline \multicolumn{1}{c}{ Características } & Tratamentos & Rep. I & Rep. II & Rep. III & Rep. IV \\
\hline \multirow{2}{*}{ ALT (cm) } & $\mathrm{P}_{0}$ & 205,46 & 210,60 & 194,41 & 198,66 \\
& $\mathrm{P}_{1}$ & 234,02 & 198,56 & 197,01 & 221,73 \\
\hline \multirow{2}{*}{ FLOR (dias) } & $\mathrm{P}_{0}$ & 44,88 & 26,69 & 36,63 & 39,08 \\
& $\mathrm{P}_{1}$ & 58,76 & 51,38 & 69,26 & 70,31 \\
\hline \multirow{2}{*}{ NPERF (por planta) } & $\mathrm{P}_{0}$ & 21,47 & 19,14 & 30,69 & 26,53 \\
& $\mathrm{P}_{1}$ & 37,77 & 45,53 & 49,08 & 39,08 \\
\hline \multirow{2}{*}{ NPAN (por planta) } & $\mathrm{P}_{0}$ & 17,67 & 18,82 & 27,57 & 23,14 \\
& $\mathrm{P}_{1}$ & 34,88 & 49,75 & 48,15 & 31,34 \\
\hline \multirow{2}{*}{ PROD (grãos em g/planta) } & $\mathrm{P}_{0}$ & 335,71 & 443,88 & 399,86 & 603,36 \\
& $\mathrm{P}_{1}$ & 445,07 & 342,19 & 535,55 & 298,24 \\
\hline \multirow{2}{*}{ PRODF (grãos em g/planta) } & $\mathrm{P}_{0}$ & 292,17 & 412,06 & 444,00 & 609,54 \\
& $\mathrm{P}_{1}$ & 514,23 & 362,99 & 559,06 & 336,04 \\
\hline \multirow{2}{*}{ PRODMS (grãos em g/planta) } & $\mathrm{P}_{0}$ & 101,76 & 186,74 & 109,64 & 199,03 \\
& $\mathrm{P}_{1}$ & 174,04 & 142,25 & 203,82 & 180,28 \\
\hline \multirow{2}{*}{ P100 (gramas) } & $\mathrm{P}_{0}$ & 0,1201 & 0,1241 & 0,1742 & 0,1436 \\
& $\mathrm{P}_{1}$ & 0,1690 & 0,2181 & 0,1296 & 0,1440 \\
\hline
\end{tabular}

Os resultados das análises de variância das variâncias das populações $\mathrm{P}_{0}$ e $\mathrm{P}_{1}$ são apresentados nas Tabelas 18 e 19 para todas as características avaliadas. 
Tabela 18. Fontes de variação (FV), graus de liberdade (GL) e quadrados médios (QM) para a análise de variância da variância dos caracteres altura de planta (ALT), dias para floração (FLOR), número de perfilhos por planta (NPERF), número de panículas por planta (NPAN) das populações $\mathrm{P}_{0}$ e $\mathrm{P}_{1}$.

\begin{tabular}{lccccc}
\hline \multicolumn{1}{c}{ FV } & $\begin{array}{c}\text { ALT } \\
\text { (cm) }\end{array}$ & $\begin{array}{c}\text { FLOR } \\
\text { (dias) }\end{array}$ & $\begin{array}{c}\text { NPERF } \\
\text { (por planta) }\end{array}$ & $\begin{array}{c}\text { NPAN } \\
\text { (por planta) }\end{array}$ \\
\hline Repetições & 3 & $0,000854^{\mathrm{ns}}$ & $0,01021^{\mathrm{ns}}$ & $0,00722^{\mathrm{ns}}$ & $0,010556^{\mathrm{ns}}$ \\
Tratamentos & 1 & $0,000892^{\mathrm{ns}}$ & $0,10885^{* *}$ & $0,12350^{*}$ & $0,14895^{*}$ \\
Erro & 3 & 0,000727 & 0,00307 & 0,00410 & 0,00728 \\
\hline CV\% & & 1,16 & 3,31 & 4,25 & 5,81 \\
Média & 2,32 & 1,67 & 1,51 & 1,46 \\
\hline
\end{tabular}

Dados transformados pela escala logaritmica, antes de se fazer cálculos para análise de variância. diferença significativa a $5 \%$ de probabilidade, ${ }^{* *}$ diferença significativa a $1 \%$ de probabilidade, ${ }^{\text {ss }}$ diferença não significativa.

Tabela 19. Fontes de variação (FV), graus de liberdade (GL) e quadrados médios (QM) para a análise de variância da variância dos caracteres produção de grãos por planta (PROD), produção de grãos de plantas férteis (PRODF), produção de grãos de plantas macho-estéreis (PRODMS), peso de 100 grãos $\left(\mathrm{P}_{100}\right)$ das populações $\mathrm{P}_{0}$ e $\mathrm{P}_{1}$.

\begin{tabular}{|c|c|c|c|c|c|}
\hline & & $\begin{array}{c}\text { PROD } \\
\text { (grãos em g/planta) }\end{array}$ & $\begin{array}{c}\text { PRODF } \\
\text { (grãos em g/planta) }\end{array}$ & $\begin{array}{c}\text { PRODMS } \\
\text { (grãos em g/planta) }\end{array}$ & $\underset{\text { (gramas) }}{P_{100}}$ \\
\hline FV & GL & $\mathbf{Q M}$ & QM & QM & $\mathbf{Q M}$ \\
\hline Repetições & 3 & $0,00268^{\mathrm{ns}}$ & $0,005825^{\mathrm{nS}}$ & $0,00834^{\text {ns }}$ & $0,00164^{\text {ns }}$ \\
\hline Tratamentos & 1 & $0,00359^{\mathrm{ns}}$ & $0,000126^{\mathrm{ns}}$ & $0,01455^{\mathrm{ns}}$ & $0,00886^{\text {ns }}$ \\
\hline Erro & 3 & 0,02173 & 0,023323 & 0,01893 & 0,01343 \\
\hline CV\% & & 5,63 & 5,80 & 6.26 & 5,33 \\
\hline Média & & 2.62 & 2,63 & 2.19 & 2.18 \\
\hline
\end{tabular}


Para todas as características, os valores de coeficiente de variação apresentados foram baixos (Tabela 18 e 19), não ultrapassaram 6,26\%.

Entre as repetições, não houve diferença estatisticamente significativa para quaisquer características no que se refere a análise de variância das variâncias (Tabela 18 e 19). Entretanto, entre os tratamentos houve diferença significativa para as características FLOR, NPERF e NPAN.

As médias apresentadas nas Tabelas 18 e 19 correspondem às médias dos dados de variâncias transformados pela escala logarítmica.

A Tabela 20 apresenta valores originais de variâncias das populações

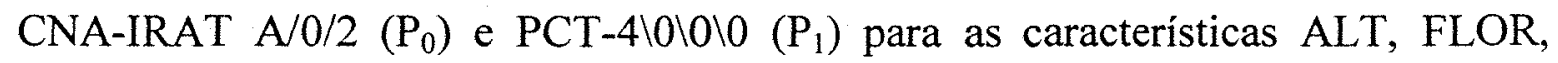
NPERF, NPAN, PROD, PRODF, PRODMS e $P_{100}$.

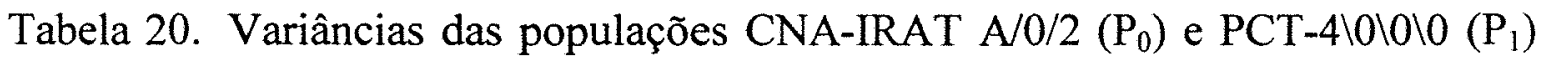
para as características altura de planta (ALT), dias para floração (FLOR), número de perfilhos por planta (NPERF), número de panículas por planta (NPAN), produção de grãos por planta (PROD), produção de grãos de plantas férteis (PRODF), produção de grãos de plantas macho-estéreis (PRODMS) e peso de 100 grãos $\left(\mathrm{P}_{100}\right)$.

\begin{tabular}{lcc}
\hline Características & Variância $^{\mathbf{1}} \mathbf{P}_{\mathbf{0}}$ & Variância $^{\mathbf{1}} \mathbf{P}_{\mathbf{1}}$ \\
\hline ALT (cm) & $201,50^{\mathrm{a}}$ & $213,83^{\mathrm{a}}$ \\
FLOR (dias) & $39,50^{\mathrm{a}}$ & $65,60^{\mathrm{b}}$ \\
NPERF (por planta) & $24,54^{\mathrm{a}}$ & $45,11^{\mathrm{b}}$ \\
NPAN (por planta) & $21,51^{\mathrm{a}}$ & $40,97^{\mathrm{b}}$ \\
PROD (grãos em g/planta) & $449,75^{\mathrm{a}}$ & $402,74^{\mathrm{a}}$ \\
PRODF (grãos em g/planta) & $438,10^{\mathrm{a}}$ & $443,12^{\mathrm{a}}$ \\
PRODMS (grãos em g/planta) & $149,35^{\mathrm{a}}$ & $174,85^{\mathrm{a}}$ \\
P100 (gramas) & $0,141^{\mathrm{a}}$ & $0,164^{\mathrm{a}}$ \\
\hline
\end{tabular}

Varâncias seguidas por letras distintas diferem entre si ao nivel de $5 \%$ ou $1 \%$ de significancia, pelo teste de $\mathrm{F}$. 
Com base na observação da Tabela 20 pode-se perceber que houve diferença entre as populações $P_{0}$ e $P_{1}$ com relação à variância, para os caracteres FLOR, NPERF e NPAN. As demais características não apresentaram diferença significativa entre as populações.

\subsection{Considerações gerais sobre as duas populações quanto aos diferentes caracteres}

\subsubsection{Altura de planta}

A população $P_{1}$ apresentou uma redução na altura de suas plantas quando comparada à população $\mathrm{P}_{0}$ de aproximadamente $8 \mathrm{~cm}(110$ para $102 \mathrm{~cm})$, conforme pode ser observado na Tabela 15. Essa alteração é desejável no programa de melhoramento, uma vez que plantas muito altas tendem a acamar (Jennings et al., 1979). A diminuição na altura foi causada pela escolha de genitores que possuem genes que condicionam essa característica. Na Tabela 16, o comportamento individual das linhagens utilizadas como genitoras fundamenta esta justificativa, uma vez que as médias das linhagens apresentam altura inferior a da população $\mathrm{P}_{0}$.

Com relação a variabilidade, ao contrário do esperado, não houve aumento na variação de $\mathrm{P}_{1}$, em relação a $\mathrm{P}_{0}$ (Tabela 20). Embora tenha havido introdução de novos genitores divergentes entre si (Tabela 16), há algumas possíveis explicações para a variabilidade não ter sido liberada. Uma delas é que podem ter sido formados blocos gênicos durante os ciclos de autofecundação 
sucessiva, típicos das plantas autógamas. Para haver liberação da variabilidade seria necessário ocorrer permuta genética durante o processo de meiose. $\mathrm{Na}$ literatura são apresentados trabalhos teóricos e práticos que afirmam que o incremento no número de gerações de recombinação não amplia a variância genética, Ospina et al. (1997) apresentam uma boa revisão sobre o assunto, entretanto, trabalhos que apontam ser necessário pelo menos um ciclo (MartinGaravito, 1994) para que ocorra a quebra desses blocos gênicos. Neste caso, a geração $P_{1}$ está no primeiro ciclo, portanto não houve tempo para haver número suficiente de permuta genética.

Borrero et al. (1995) afirmam que o processo de formação de uma nova população deve ter uma etapa de recombinação dos genitores introduzidos antes de se iniciar o trabalho cíclico do método, portanto, nesta fase estaria havendo liberação de variabilidade. Uma segunda possibilidade seria que a amostra

retirada para representar $P_{1}$ pode ter sido pequena, de maneira que não tenha conseguido demonstrar toda a variabilidade existente.

\subsubsection{Dias para floração}

A população $P_{1}$ apresentou um aumento no número médio de dias para floração quando comparada com a população $\mathrm{P}_{0}$, de aproximadamente 76 para 79 dias, conforme apresentado na Tabela 15. A utilização de parentais como $\mathrm{L}_{2}, \mathrm{~L}_{3}$ e $\mathrm{L}_{4}$ pode ter favorecido para que isso ocorresse (Tabela 16). Uma vez que em programas de melhoramento genético a precocidade é uma característica desejada, esse aumento no número médio de dias para florescimento ocorrida na população $\mathrm{P}_{1}$ quando comparada a $\mathrm{P}_{0}$, poderia indicar um aspecto desfavorável; entretanto, ambas as populações estão classificadas como "precoces" e portanto, esse aumento no número de dias não indica prejuízo significativo. 
Châtel et al., (1995) ao descreverem as populações CNA-IRAT 5, CNA-IRAT A, CNA-IRAT-P e IRAT Lulu classificam as plantas com menos de 74 dias para floração como sendo "muito precoces", de 75 - 84 dias para floração como "precoces", de 85 - 94 como "intermediário" e acima de 94 dias como "tardio", usando o Sistema de Avaliação Padrão para arroz, proposto pelo IRRI (1988).

No caso do arroz de sequeiro, a precocidade impede que a cultura fique exposta a veranico ou a fatores bióticos. Outra vantagem é quando existe a associação do arroz com gramíneas forrageiras, o agricultor tem a possibilidade de garantir a formação do pasto tendo lucro com a venda do arroz (Breseghello \& Castro, 1998; Ospina et al., 1998a).

Com relação à variância, houve um aumento significativo de $\mathrm{P}_{1}$, em relação a $\mathrm{P}_{0}$ (de aproximadamente 39 para 66 dias $^{2}$ ), conforme pode ser observado na Tabela 20. Esse fato representa que mesmo tendo sido aumentado o número médio de dias para a floração da população $\mathrm{P}_{1}$, há possibilidade de se encontrar genótipos favoráveis (mais precoces) a serem selecionados. A ampliação da variabilidade foi causada pela utilização de parentais que diferiam entre si (Tabela $16)$.

\subsubsection{Número de perfilhos por planta}

Houve aumento significativo no número de perfilhos por planta da população $\mathrm{P}_{1}$ em relação a $\mathrm{P}_{0}$, de aproximadamente 13 para 17 perfilhos, conforme mostra a Tabela 15. Nesse caso, as linhagens $L_{2}, L_{3}$ e $L_{4}$ parecem ter exercido grande influência no comportamento de $\mathrm{P}_{1}$ (Tabela 16).

Quanto à variância, também houve aumento significativo de $\mathrm{P}_{1}$ em relação a $\mathrm{P}_{0}$ de aproximadamente 24 para 45 (perfilhos/planta) ${ }^{2}$, conforme apresenta a Tabela 20. O fato de haver diferença significativa dentre os parentais utilizados (Tabela 16) poderia ter gerado aumento na variabilidade desse caráter. 
Mesmo existindo apenas duas classes, segundo o teste de Tukey, os materiais contrastavam bastante entre si.

Segundo Morais et al. (1997a) o programa de melhoramento de arroz de sequeiro procura plantas com maior capacidade de perfilhamento visando maior produtividade, embora alguns outros programas tenham afirmado que o potencial máximo de rendimento seria conseguido com plantas de perfilho único. $O$ autor explica que estas variedades com altos potenciais de perfilhamento poderiam produzir poucos perfilhos sob alta densidade de plantio e poderiam aumentar a produção de grãos por unidade de área, devido a plasticidade para compensação de falhas. Desta maneira, a adequada seleção de plantas com vários perfilhos poderia garantir um acúmulo de genes favoráveis para essa característica nas gerações seguintes.

\subsubsection{Número de panículas por planta}

Houve aumento significativo no número médio de panículas por planta, da população $P_{0}$ em relação a $P_{1}$ de aproximadamente 12 para 15 panículas, conforme mostra a Tabela 15. Observando-se a Tabela 16, pode-se sugerir que as linhagens $L_{2}, L_{3}$ e $L_{4}$ devem ter sido as que mais exerceram influência para o comportamento da população $P_{1}$ em relação a sua média.

Houve aumento significativo na variância de $P_{1}$ em relação a $P_{0}$ (Tabela 20), de aproximadamente 21 para 41 (panículas/planta) ${ }^{2}$, e esse aumento deve ter sido condicionado pelas diferenças entre as linhagens (Tabela 16). Tratase de situação semelhante a da característica NPERF. Embora existam poucas classes de tratamentos, segundo o teste de Tukey, elas divergem bastante entre si.

O aumento na média dessa característica já representa uma melhora na população $\mathrm{P}_{1}$ em relação a $\mathrm{P}_{0}$, uma vez que essa é uma característica relacionada 
diretamente com a produtividade da planta e o aumento na variância indica potencial da população para o melhoramento, uma vez que existindo maior diversidade na população há maiores chances de ocorrência de genótipos favoráveis a serem selecionados.

\subsubsection{Produção de grãos por planta em plantas férteis e macho- estéreis}

Ao se comparar a característica produção entre as populações $\mathrm{P}_{0}$ e $\mathrm{P}_{1}$, verificou-se não haver diferenças estatisticamente significativas entre elas em termos de média ou variância. Mesmo ao se separar as populações em plantas férteis e estéreis (PRODF e PRODMS) não foram apresentadas diferenças entre as populações. A diminuição no valor média da população $P_{1}$ em relação a $P_{0}$, mesmo que estatisticamente não significativa (Tabela 15), pode ter sido causada pela utilização de parentais que sempre apresentavam valores menores que $\mathrm{P}_{0}$ (Tabela 16).

A falta de aumento de variabilidade em $\mathrm{P}_{1}$ para PROD, PRODF e PRODMS (Tabela 20) pode ter sido causada pela homogeneidade dos parentais utilizados, com relação à essa característica (Tabela 16).

Trata-se de uma característica com a qual o melhorista deverá se preocupar nas gerações futuras. Estes fatos deverão levar a utilização de novas estratégias de melhoramento com relação a essa característica, como por exemplo, a realização de novos cruzamentos, com parentais favoráveis e/ou divergentes entre si.

\subsubsection{Peso de 100 grãos}

Houve diminuição no peso de 100 grãos da população $\mathrm{P}_{1}$ em relação a $\mathrm{P}_{0}$, de 3,45 para $3,07 \mathrm{~g}$ (Tabela 15). Constata-se, com base na análise da Tabela 
16, que os parentais $\mathrm{L}_{2}, \mathrm{~L}_{3}$ e $\mathrm{L}_{4}$ influenciaram o comportamento da população $P_{1}$ para uma queda no peso de 100 grãos. Com relação à variância, não houve diferença estatisticamente significativa entre as populações $\mathrm{P}_{0}$ e $\mathrm{P}_{1}$, sendo de 0,1645 para $0,1410(\mathrm{~g} / \text { planta })^{2}$, respectivamente, conforme apresentado na Tabela 20 .

A utilização de linhagens tão contrastantes entre si como parentais deveria ter provocado um aumento na variabilidade, entretanto isso não ocorreu, e assim como foi explicado para a característica ALT, é possível que tenham sido formados blocos gênicos durante os ciclos de autofecundação sucessiva e novos ciclos de recombinação sejam necessários para que a variabilidade seja liberada.

\subsection{Estimativas de parâmetros genéticos e fenotípicos.}

Nas Tabelas 21 a 27 são apresentadas as análises de variância dentro de populações e linhagens para os caracteres ALT, FLOR, NPERF, NPAN, PROD, PRODF e $\mathrm{P}_{100}$. A variação nos graus de liberdade está relacionada a diferentes números de plantas avaliadas para cada característica.

Tabela 21. Variâncias dentro de populações para a característica altura de planta.

\begin{tabular}{llcc}
\hline FV & GL & SQ & QM \\
\hline ENTRE PLANTAS/P $/$ R & 426 & 85839,08 & $201,50^{* *}$ \\
ENTRE PLANTAS/P $1 / R$ & 419 & 89594,77 & $213,83^{* *}$ \\
ENTRE PLANTAS/T/R & 388 & 14534,48 & 37,46 \\
\hline F. & & &
\end{tabular}

Tabela 22. Variâncias dentro de populações para a característica dias para floração.

\begin{tabular}{llcc}
\hline FV & GL & SQ & QM \\
\hline ENTRE PLANTAS/P/R & 426 & 16827,03 & $39,50^{* *}$ \\
ENTRE PLANTAS/P $/$ R & 419 & 27486,42 & $65,60^{* *}$ \\
ENTRE PLANTAS/T/R & 388 & 4543,48 & 11,71 \\
\hline diferença significativa a $5 \%$ de probabilidade, " diferença significativa a 1\% de probabilidade, ${ }^{n+1}$ diferença não significativa pelo teste \\
F.
\end{tabular}


Tabela 23. Variâncias dentro de populações para a característica número de perfilhos por planta.

\begin{tabular}{lccc}
\hline FV & GL & SQ & QM \\
\hline ENTRE PLANTAS/P $/$ R & 427 & 10478,58 & $24,54^{\text {ns }}$ \\
ENTRE PLANTAS/P $/$ R & 418 & 18855,98 & $45,11^{* *}$ \\
ENTRE PLANTAS/T/R & 387 & 7832,88 & 20,24 \\
\hline diferença significativa a $5 \%$ de probabilidade, " diferença significativa a 1\% de probabilidade, ", diferença não significativa pelo teste \\
F.
\end{tabular}

Tabela 24. Variâncias dentro de populações para a característica número de panículas por planta.

\begin{tabular}{llcl}
\hline FV & GL & SQ & QM \\
\hline ENTRE PLANTAS/P/R & 443 & 9719,42 & $21,94^{\text {ns }}$ \\
ENTRE PLANTAS/P/R $/ R$ & 477 & 20358,36 & $42,68^{* *}$ \\
ENTRE PLANTAS/T/R & 406 & 8619,38 & 21,23 \\
\hline "diferença significativa a 5\% de probabilidade, " diferença significativa a 1\% de probabilidade, " diferença não significativa pelo teste \\
F.
\end{tabular}

Tabela 25. Variâncias dentro de populações para a característica produção de grãos por planta.

\begin{tabular}{|c|c|c|c|}
\hline FV & GL & SQ & QM \\
\hline ENTRE PLANTAS/P $/ \mathrm{R}$ & 417 & 187545,75 & $449,75^{* *}$ \\
\hline ENTRE PLANTAS $/ \mathrm{P}_{1} / \mathrm{R}$ & 491 & 197745,34 & $402,74^{* *}$ \\
\hline ENTRE PLANTAS/T/R & 377 & 61420,84 & 162,92 \\
\hline
\end{tabular}


Tabela 26. Variâncias dentro de populações para a característica produção de grãos de plantas férteis.

\begin{tabular}{lccc}
\hline \multicolumn{1}{c}{ FV } & GL & SQ & QM \\
\hline ENTRE PLANTAS/P/R & 248 & 108648,87 & $438,10^{* *}$ \\
ENTRE PLANTAS/P/R & 267 & 118307,74 & $443,10^{* *}$ \\
ENTRE PLANTAS/T/R & 377 & 61420,84 & 162,92 \\
\hline 'diferença significativa a 5\% de probabilidade, " diferença significativa a $1 \%$ de probabilidade, ${ }^{\text {ns }}$ diferença não significativa pelo teste \\
F.
\end{tabular}

Tabela 27. Variâncias dentro de populações para a característica peso de 100 grãos.

\begin{tabular}{llll}
\hline FV & GL & SQ & QM \\
\hline ENTRE PLANTAS/P0/R & 457 & 64,437 & $0,1410^{* *}$ \\
ENTRE PLANTAS/P $1 /$ R & 484 & 79,618 & $0,1645^{* *}$ \\
ENTRE PLANTAS/T/R & 402 & 17,407 & 0,0433 \\
\hline "diferença significativa a 5\% de probabilidade, " diferença significativa a 1\% de probabilidade, ${ }^{n \text { s }}$ diferença não significativa pelo teste \\
F.
\end{tabular}

As Tabelas 21 a 27 indicam que há diferenças estatisticamente significativas entre plantas da população $\mathrm{P}_{0}$ para as características ALT, FLOR, PROD, PRODF e $\mathrm{P}_{100}$ e entre plantas da população $P_{1}$ para as características ALT, FLOR, NPERF, NPAN, PROD e PRODF e $\mathrm{P}_{100}$. A existência de variabilidade entre plantas dentro da população indica haver possibilidade de ser feita seleção de melhores genótipos, tomando-se assim, interessante para os programas de melhoramento genéticos.

Na Tabela 28 são apresentadas as estimativas da variância genética, da variância ambiental, da média, do coeficiente de variação ambiental, do 
coeficiente de variação genético, do coeficiente b e do coeficiente de herdabilidade para as populações $\mathrm{P}_{0}$ e $\mathrm{P}_{1}$, para as características ALT, FLOR, NPERF, NPAN, PROD e $P_{100}$.

Tabela 28. Estimativas de variância ambiental e genética para as duas populações e respectivas estimativas de parâmetros genético-estatísticos para as características altura de planta (ALT), dias para floração (FLOR), número de perfilhos por planta (NPERF), número de panículas por planta (NPAN), produção de grãos por planta (PROD) e peso de 100 grãos $\left(\mathrm{P}_{100}\right)$.

\begin{tabular}{|c|c|c|c|c|c|c|}
\hline PARÂMETROS & ALT & FLOR & NPERF & NPAN & PROD & P $_{100}$ \\
\hline$\hat{\sigma}_{g P_{0}}^{2}$ & 164,04 & 27,79 & 4,30 & 0,71 & 286,83 & 0,0977 \\
\hline$\hat{\sigma}_{g P_{1}}^{2}$ & 176,37 & 53,89 & 24,87 & 21,45 & 239,82 & 0,1212 \\
\hline$\hat{\sigma}_{e}^{2}$ & 37,46 & 11,71 & 20,24 & 21,23 & 162,92 & 0,0433 \\
\hline $\bar{X}$ & 102,73 & 78,00 & 14,95 & 13,80 & 28,23 & 3,13 \\
\hline$C V_{e}$ & 5,96 & 4,39 & 30,09 & 33,38 & 45,21 & 6,65 \\
\hline$C V_{g_{P_{0}}}$ & 11,66 & 6,94 & 16,06 & 7,08 & 52,17 & 9,06 \\
\hline$C V_{g P_{1}}$ & 12,97 & 9,24 & 28,91 & 30,07 & 61,02 & 11,34 \\
\hline$b_{P_{0}}$ & 1,96 & 1,58 & 0,53 & 0,21 & 1,15 & 1,36 \\
\hline$b_{P_{1}}$ & 2,18 & 2,10 & 0,96 & 0,90 & 1,34 & 1,70 \\
\hline$\hat{h}_{P_{v}}^{2} \%$ & 81,41 & 70,35 & 17,52 & 3,20 & 63,77 & 69,29 \\
\hline$\hat{h}_{P_{1}}^{2} \%$ & 82,48 & 82,15 & 55,13 & 50,25 & 59,54 & 73,67 \\
\hline
\end{tabular}


Com base na observação da Tabela 28 foi possível verificar que a variância genética de $P_{1}$ foi bem maior do que a de $P_{0}$ para os caracteres FLOR, NPERF e NPAN. Esses dados estão de acordo com os de variância fenotípica apresentados na Tabela 20, onde houve diferença significativa entre as populações para estas mesmas características. $\mathrm{O}$ aumento na variância de uma população para outra indica ter sido atingido o objetivo de ampliação da base genética da cultura através do cruzamento de vários parentais com a população $\mathrm{P}_{0}$ para ser formada a população $\mathrm{P}_{1}$. Além disso, o aumento na variabilidade de uma população é um indício da possibilidade de surgirem genótipos favoráveis em programas de melhoramento, através da seleção adequada de genótipos.

Os parâmetros genéticos como coeficiente de variação genético $\left(\mathrm{CV}_{\mathrm{g}}\right)$, b e herdabilidade $\left(\mathrm{h}^{2}\right)$ indicam a possibilidade de sucesso nas etapas de seleção.

Segundo VENCOVSKY (1987) o índice b sendo próximo a 1, representa uma situação muito favorável à seleção. Ao analisar este item isoladamente verifica-se que para todas as características, esse valor apresentou-se maior na população $P_{1}$ do que na população $P_{0}$, indicando que a $P_{1}$ é mais indicada para ser utilizada em um programa de melhoramento. Embora para as características NPERF e NPAN esses valores tenham sido menores que 1, eles praticamente dobraram e quadruplicaram quando comparados à população $\mathrm{P}_{0}$.

Os valores de $\mathrm{CV}_{\mathrm{g}}$ mais altos foram apresentados para as características PROD e NPERF para ambas as populações e NPAN para a população $\mathrm{P}_{1}$. Nas populações obtidas por Morais et al. (1998), Rangel et al. (1998), Rodriguez et al. (1998) e Santos et al. (1997) também foram apresentados altos valores de $\mathrm{CV}_{\mathrm{g}}$ para a característica $\mathrm{PROD}$, indicando que essa é uma característica favorável para a seleção. Embora generalizações como esta não sejam muito indicadas pelo fato de cada população ter uma característica diferente da outra, elas servem como referência. 
Ao se comparar entre si os dados de $\mathrm{CV}_{\mathrm{e}}$ apresentados na Tabela 28 verificou-se que os valores mais altos foram para as características NPERF, NPAN e PROD sugerindo assim que essas são as características mais influenciadas pelo ambiente.

Os coeficiente de herdabilidade $\left(\mathrm{h}^{2}\right)$ das características ALT, PROD e $\mathrm{P}_{100}$ apresentaram-se semelhantes para as duas populações. Para as outras características, a população $P_{1}$ sempre apresentou valores mais elevados.

A caracteristica ALT apresentou altos índices de herdabilidade para as duas populações ( $81,4 \%$ e $82,5 \%$ respectivamente). Esses índices concordam com o apresentado na literatura por Datke et al. (1997); Mehtre et al. (1996), Saravanan \& Senthil (1997) e Verma et al. (1994). Este último autor indica não haver efeito de dominância controlando esse caráter, o que permite que a seleção seja mais eficiente. Associando estes dados com os valores de $\mathrm{b}$ e de $\mathrm{CV}_{\mathrm{g}}$ pode-se afirmar que a seleção para esse caráter já nos primeiros ciclos de seleção seria efetiva, concordando com a explicação dada por Rao (1996). Para esta característica não existe diferença em se trabalhar com a população $P_{0}$ ou $P_{1}$ em termos de ganho com seleção. $O$ fato de não haver diferença significativa entre as variâncias fenotípicas das duas populações corrobora com a explicação acima (Tabela 20). A diminuição na média da altura de $P_{1}$ em relação a $P_{0}$ (Tabela 15) entretanto, demonstrou que $\mathrm{P}_{1}$ apresenta-se mais promissora dentro de um programa de melhoramento.

Para as características FLOR, NPERF e NPAN houve um aumento no valor de herdabilidade para a população $\mathrm{P}_{1}$, indicando que ela tornou-se mais apropriada para a seleção. Para a característica FLOR, como os valores de herdabilidade apresentados foram altos, isso indica que ganhos substanciais com seleção poderão ser observados nos primeiros ciclos. Verma et al., (1994), Datke et al. (1997), Saravanan \& Senthil (1997), Sharma \& Hore (1997), Almeida et al. (1998), também encontraram valores altos de herdabilidade para a característica 
FLOR. As caracteristicas NPERF e NPAN apresentaram valores intermediários de herdabilidade para a população $\mathrm{P}_{1}$ e valores baixos de herdabilidade para a população $\mathrm{P}_{0}$, indicando que em $\mathrm{P}_{1}$ a seleção poderá ser mais eficiente que em $\mathrm{P}_{0}$. Ashvani et al. (1997) encontrou altos valores de herdabilidade para número de panículas; já Almeida et al. (1998) e Morais et al. (1997b) encontraram valores intermediários e baixos. Para a característica NPERF Saravanan \& Senthil (1997) encontraram altos valores de herdabilidade e Basavaraja et al. (1997) e Mishdra et al. (1996) encontraram baixos valores.

A característica $P_{100}$ também apresentou valores altos de herdabilidade, concordando com Almeida et al. (1998), Ashvani et al. (1997), Chaubey \& Singh (1994), Morais et al. (1998) e diferindo de Rodriguez et al., (1998). Esse fato também evidencia a facilidade de selecionar precocemente para essa característica nesta população. $\mathrm{O}$ alto valor de $\mathrm{b}$ está associado a este fato. Ao se comparar as médias das populações $\mathrm{P}_{0}$ e $\mathrm{P}_{1}$ (Tabela 15) verifica-se ter havido uma diminuição no $P_{100}(3,45$ para $3,07 \mathrm{~g})$. A seleção dos genótipos mais produtivos poderá minimizar este problema já nos primeiros ciclos.

A característica produção apresentou alta herdabilidade para as populações $\mathrm{P}_{0}$ e $\mathrm{P}_{1}$. A pequena diminuição que houve no valor de $\mathrm{P}_{1}$ em relação a $\mathrm{P}_{0}$, foi devido a diminuição na quantidade de variância genética de $\mathrm{P}_{1}$. Este fato, entretanto, não foi significativo, por não haver diferença significativa entre as populações (Tabela 20). Neste caso, a seleção deverá ser eficiente, pois os valores de herdabilidade são relativamente altos, assim como os valores de b. Os outros autores que encontraram altos valores de herdabilidade para a característica produção foram Ashvani et al. (1997), Datke et al. (1997), Sharma \& Hore (1997), Rangel et al. (1998), Rodriguez et al. (1998) e os que encontraram intermediários e baixos valores foram Basavaraja et al. (1997) e Morais et al. (1997). 
Quanto maior a herdabilidade, maior o ganho genético por seleção (Falconer, 1978). Dessa maneira, as características ALT, FLOR e $\mathrm{P}_{100}$ são mais promissoras para o melhoramento em ambas as populações.

Entretanto, a população $P_{1}$ apresentou-se mais favorável que a população $\mathrm{P}_{0}$ para o melhoramento genético das características FLOR, NPERF e NPAN. 


\section{CONCLUSÕES}

A análise dos dados e a interpretação dos resultados obtidos permitiram chegar às seguintes conclusões:

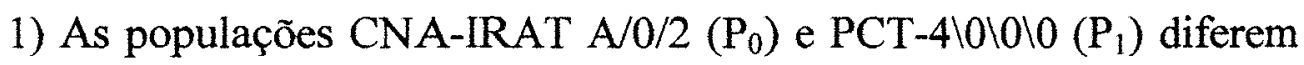
entre si em termos de média para as características altura da planta, dias para floração, número de perfilhos por planta, número de panículas por planta e peso de 100 grãos.

2) A população $P_{1}$ foi considerada melhor que $P_{0}$ por ter apresentado diminuição na característica altura da planta e aumento em número de perfilhos por planta e número de panículas por planta.

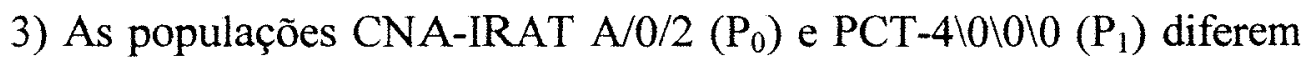
entre si em termos de variância para as características dias para floração, número de perfilhos por planta e número de panículas por planta.

4) A população $P_{1}$ apresenta-se mais favorável ao melhoramento genético para as características dias para floração, número de perfilhos por planta, número de panículas por planta que a população $\mathrm{P}_{0}$. Para as demais características, ambas as populações apresentam o mesmo potencial. 


\section{REFERÊNCIAS BIBLIOGRÁFICAS}

ALLARD, R.W. Princípios do melhoramento genético das plantas. São Paulo: Edgar Blucher, 1971. 381p.

ALMEIDA, J.A.; PEREIRA, J.A.; GOMES, R.L.F. Análise genética de famílias $\mathrm{S}_{0: 2}$ de arroz irrigado. Genetics and Molecular Biology, v.21, n.3, p. 209, 1998.

ASHVANI, P.; DHAKA, R.P.S; SHARMA, R.K.; ARYA, K.P.S. Genetic variability and inter-relationship in rice (Oryza sativa L.) Advances in Plant Sciences. v. 10, n.1, p.29-32, 1997. /Resumo em CAB Abstracts on CDROM, 1996-98/

BASABARAJA, P.; RUDRARADHYA, M.; KULKARNI, R.S. Genetic variability, correlation and path analysis of yield components in two $F_{4}$ population of fine grained rice. Mysore Journal of Agricultural Sciences, v. 31, n.1, p.1-6, 1997. /Resumo em CAB Abstracts on CD-ROM, 1996-98/

BORÉM, A. Melhoramento de plantas. Viçosa: UFV, 1997. 547p.

BORRERO-C., J.; OSPINA-R., Y.; GUIMARÃES, E.P.; CHÂTEL, M. Ampliación de la base genética por la introduccion de variabilidad en poblaciones y acervos de genes segregando para un gen recessivo de androesterilidad In: TAILLER INTERNACIONAL DE SELECCIÓN RECURRENTE DE ARROZ, Goiânia, Goiás, 1995. Goiânia: EMBRAPA, CNPAF, 1995. p.155-165.

BRESEGHELLO, F.; CASTRO, E.M. Avaliação de cultivares e linhagens de arroz para plantio consorciado com capim. In: REUNIÃO NACIONAL DE PESQUISA DE ARROZ, 6., Goiânia, 1998. Perspectivas para a cultura do arroz nos ecossistemas de várzeas e terras altas; resumos expandidos. Goiânia: EMBRAPA-CNPAF, 1998. p.265-267. 
CHANDRARATNA, M.F. Genetics and breeding of rice. London: Butler \& Tanner, 1963. 379p.

CHÂTEL, M.; GUIMARÃES, E.P. Seleccion recurrente en arroz en Africa y Madagascar. In: GUIMARÃES, E.P (Ed.) Seleccion recurrente en arroz. Cali, Colombia: CIAT, 1997. cap. 12, p.151-164.

CHÂTEL, M.; GUIMARÃES, E.P. Recurrent selection in rice gene pools and populations. Review of present status and progress In: TAILLER INTERNACIONAL DE SELECCIÓN RECURRENTE DE ARROZ, Goiânia, Goiás, 1995. Goiânia: EMBRAPA, CNPAF, 1995. p. 240-269.

CHAUHAN, J.S. Inheritance of grain weight, size and shape in rainfed rice (Oryza sativa). Indian Journal of Agricultural Sciences, v.68, n.1, p.9-12, 1998. /Resumo em CAB Abstracts on CD-ROM, 1996-98/

CHAUBEY, P.K.; SINGH, R.P. Genetic variability, correlation and path analysis of yield components of rice. Madras agricultural Journal, v.81, n.9, p.468470, 1994. /Resumo em CAB Abstracts on CD-ROM, 1996-98/

CHAUHAN, J.S. Inheritance of high - density grain index in an upland rice (Oryza sativa) cross. Indian Journal of Agricultural Sciences, v.67, n.10, p.444-446, 1997. /Resumo em CAB Abstracts on CD-ROM, 1996-98/

\section{CIAT ANNUAL REPORT 1994}

CUEVAS-PEREZ, F.E.; GUIMARÃES, E.P.; BERRIO, L.E.; GONZALES, D.I. Genetic base of irrigated rice in Latin America and the caribbean, 1971 to 1989. Crop Science, v.32, p.1054-1059, 1992.

DATKE, S.B.; KANDALDAR, H.G.; WEGINWAR, D.G.; ALLURWAR, A.W. Study on variability in advanced generations of paddy strains. Journal of Soils and Crops. v.7, n.2, p.190-195, 1997. /Resumo em CAB Abstracts on CDROM, 1996-98/

DILDAY, R.H. Contribution of ancestral lines in the development of new cultivars of rice. Crop Science, v.30, p.905-911, 1990.

FALCONER, D.S. Introdução à genética quantitativa. Viçosa: UFV, Impr. Univ., 1987.279p.

GUIMARÃES, E.P. Seleccion recurrente en arroz. Cali: CIAT, 1997. 240p. 
GUIMARÃES, E.P. Genealogy of brazilian upland rice cultivars. International Rice Research Notes, v.18, n.1, p.6, 1993. Pesquisa Agropecuária Brasileira, v.31, n.3, p.187-194, mar 1996.

HARGROVE, T.R.; COFFMAN, W.R.; CABANILLS, V.L. Ancestry improved cultivars of Asian rice. Crop Science, v.20, p.721-727, 1980.

JENNINGS, P.R.; COFFMAN, W.R.; KAUFFMAN, H.E. El mejoramieno de arroz. In: TASCON, E.J.; GARCIA, E.D. (Ed.) Arroz: investigacion y producion. Cali: CIAT, 1985. p.205-232.

MARTIN-GARAVITO, J. M. Efecto de número de ciclos de recombinación en la variabilidad de poblaciones de arroz (Oryza sativa L.). Palmira, 1994. 50p. Monografia (Graduação) - Facultad de Ciencias Agropecuárias de Palmira, Universidad Nacional de Colombia.

MEHTRE, S.S.; MAHAJAN, C.R.; PATIL, P.A.; DHUMAL, P.M. Variability, heritability, correlation, path analysis and genetic divergence studies in $\mathrm{M}_{2}$ generation of gamma-irradiated upland rice. International Rice Research Notes, v.21, n.2-3, p.56-58, 1996. /Resumo em CAB Abstracts on CD-ROM, 1996-98/

MISHRA, D.K.; SINGH, C.B.; RAO, S.K. Effectiveness of different selection methods in segregating population of rice (O. sativa L.) in ARC10372 x IR36 in different environments. Indian Journal of Genetics and Plant Breeding. v.54, n. 4, p.402-408, 1996. /Resumo em CAB Abstracts on CD-ROM, 1996$98 /$

MONTALVAN, R.; DESTRO, D.; SILVA, E.F.; MONTAÑO, J.C. Genetic base of brazilian upland rice cultivars. Journal of Genetics and Breeding, v.53, p.63-69, 1998.

MORAIS, O.P.; CASTRO, E.M.; SANT'ANA, E.P. Selección recurrente en arroz de secano en Brasil. In: GUIMARÃES, E.P (Ed.) Seleccion recurrente en arroz. Cali: CIAT, 1997a. cap. 8, p.99-115.

OSPINA-R., Y.; BORRERO-C., J.; GUIMARÃES, E.P.; CHÂTEL, M. Ciclos de intercruzamiento y variabilidad genética en poblaciones de arroz. In: GUIMARÃES, E.P (Ed.) Seleccion recurrente en arroz. Cali: CIAT, 1997. cap.4, p.45-53.

OSPINA-R., Y.; CHÂTEL, M.; GUIMARÃES, E.P.; BORRERO-C., J. Mejoramiento poblacional de arroz de sabanas para precocidad. In: REUNIÃO NACIONAL DE PESQUISA DE ARROZ, 6., Goiânia, 1998. Perspectivas 
para a cultura do arroz nos ecossistemas de várzeas e terras altas: resumos expandidos. Goiânia: EMBRAPA, CNPAF, 1998a. p.289-292.

PARAMASIVAN, K.S. Heritability and genetic advance in hybrids of dwarf and tall indica rice (Oryza sativa L.). Madras agricultural Journal, v.68, n.2, p.135-137, Feb. 1981.

PIMENTEL-GOMES, F. Curso de estatística experimental. Piracicaba: Nobel, 1990. 468p.

RANGEL, P.H.N.; GUIMARÃES, E.P.; NEVES, P.C.F. Base genética das cultivares de arroz (Oryza sativa L.) irrigado do Brasil. Pesquisa Agropecuária Brasileira, v.31, n.5, p.349-347, maio 1996.

RANGEL, P.H.N.; NEVES, P.C.F. Seleção recorrente em arroz irrigado no Brasil: guia prático. Goiânia: EMBRAPA, CNPAF, 1995. 24p.

RANGEL, P.H.N.; ZIMMERMANN, F.J.P. Ganhos de produtividade de grãos no melhoramento populacional do arroz de várzea. In: REUNIÃO NACIONAL DE PESQUISA DE ARROZ, 6., Goiânia, 1998. Perspectivas para a cultura do arroz nos ecossístemas de várzeas e terras altas; resumos expandidos. Goiânia: EMBRAPA, CNPAF, 1998. p.174-175.

RAO, T.P.; GOMATHINAYAGAM, P.; SOUNDRAPANDIAN, G. Genetic variability and character association studies in semi-dry rice. Madras Agricultural Journal, v.83, n.3, p.185-188, 1996. /Resumo em CAB Abstracts on CD-ROM, 1996-98/

RODRIGUEZ, R.E.S.; RANGEL, P.H.N.; MORAIS, O.P. Estimativas de parâmetros genéticos e de respostas à seleção na população de arroz irrigado CNA 1. Pesquisa Agropecuária Brasileira, v.33, n.5, p.685-691, maio 1998.

SAKAI, K.I. Problems in selection in rice. International Rice Comission Newsletter, n. spec., p.7-16, 1963.

SAKAI, K.I.; NILES, J.J. Heritability of grain shedding and other characters in rice. Tropical Agriculturist, v.113, p.211-218, 1957.

SANTOS, P.G.; SOARES, A.A.; RAMALHO, M.A.P. Estimates of genetic and phenotypic parameters in a segregant population of rice irrigated by continuous floding. Brazilian Journal of Genetics, v.20, n.3, p.429-433, 1997.

SARAVANAN, R.; SENTHIL, N. Genotypic and phenotypic variability, heritability and genetic advance in some important traits in rice. Madras 
Agricultural Journal, v.84, n.5, p.276-277, 1997. /Resumo em CAB Abstracts on CD-ROM, 1996-98/

SHARMA, B.D.; HORE, D.K. Yield attributes of rice (Oryza sativa L.) under acidic, low-phosphorus and high iron soils of north-eastern region of India. Indian Journal of Agricultural Sciences. v.67, n.12, p.580-582, 1997. /Resumo em CAB Abstracts on CD-ROM, 1996-98/

SINGH, R.J.; IKEHASHI, H.I. Monogenic male sterility in rice: Induction, identification and inheritance. Crop Science, Madison, v.21, p.286-289, 1981.

VEGA, U. Mejoramiento genetico de plantas. Maracay, Venezuela: Ideograf, 1988. 200p.

VENCOVSKY, R. Herança quantitativa. In: PATERNIANI, E.; VIEGAS, G.P. (Ed.). Melhoramento e produção de milho. Campinas: Fund. Cargill, 1987. v.1, p.135-214.

VERMA, P.K.; KATOCH, P.C.; KAUSHIK, R.P. Genetics of harvest index and grain characters eliminating and allowing the inadequacy of testers using selfing generation of triple test cross in rice. Annals of Biology Ludhiana. v.10, n.2, p.216-222, 1994. /Resumo em CAB Abstracts on CD-ROM, 1996-98/ 